\title{
Economic Crises and the European Revolutions of 1848
}

\author{
HELGE BERGER AND MARK SPOERER
}

\begin{abstract}
Recent historical research tends to view the 1848 revolutions in Europe as caused by a surge of radical ideas and by long-term socioeconomic problems. However, many contemporary observers interpreted much of the upheaval as a consequence of shortterm economic causes, specifically the serious shortfall in food supply that had shaken large parts of the Continent in 1845-1847, and the subsequent industrial slump. Applying standard quantitative methods to a data set of 27 European countries, we show that it was mainly immediate economic misery, and the fear thereof, that triggered the European revolutions of 1848.
\end{abstract}

$I^{n}$

$\mathrm{n}$ the 1990s the acceleration of economic and political integration in Western Europe and the democratization of Eastern Europe led to an increasing interest in the turbulent year 1848, when large parts of the Continent experienced a striving for political participation and self-determination. ${ }^{1}$ The recent sesquicentennial has given rise to a wealth of literature, especially in countries where 1848 meant a first step towards more democratic political institutions, including Germany, Austria, Hungary, and Romania. Many of these studies reflect the scholarly trend away from social history. To be sure, even after the "cultural turn" most historians concede that structural socioeconomic problems contributed to rising popular discontent. But whereas in the 1970s and 1980s long- and shortterm socioeconomic determinants were pivotal in explanations of the 1848 revolutions, short-term economic factors now tend to be marginalized; instead, greater weight is placed on the spread of liberal and democratic ideas, and on the inflexible and increasingly outdated political institutions of the time, which were ill-suited to cope with the societal

The Journal of Economic History, Vol. 61, No. 2 (June 2001). (C) The Economic History Association. All rights reserved. ISSN 0022-0507.

Helge Berger, CES, University of Munich, and CESifo; Mark Spoerer, University of Hohenheim, Stuttgart; e-mail: spoerer@ uni-hohenheim.de. Address correspondence to Helge Berger, CES, Schackstrasse 4, 80539 Munich, Germany. E-mail: h.berger@ces.vwl.uni-muenchen.de.

The article has benefited greatly from discussions at the 1848 Conference in Offenburg, seminars at the Universitat Pompeu Fabra (Barcelona), the Center for Comparative History of Europe (Berlin), and the 1998 EHA Meeting in Durham, NC. Rolf Dumke, Timothy Guinnane, Bertrand Roehner, Richard Tilly, Eugene White, and especially Sheilagh Ogilvie provided very helpful comments and suggestions. We would also like to thank Jonas Ljungberg, Lars Svensson, Jan Luiten van Zanden, and other members of the discussion group EH.RES for providing useful references and data. Michael Kopsidis was kind enough to provide data on Prussian grain prices compiled from archival sources. Additional comments by the editor, Jan de Vries, the assistant editor, Heath Pearson, and a referee considerably improved the article.

${ }^{1}$ See for example Kaelble, "1848." 
problems of early industrialization. ${ }^{2}$ Surprisingly few authors stress the deep economic crisis that immediately preceded the revolutionary events: witness the plethora of monographs that mention short-run economic factors not at all or only in passing, and the many edited volumes that lack a single paper on the economic crisis preceding the events of $1848 .^{3}$

But while ideas and institutions undoubtedly contribute to our understanding of the general preconditions for the upheaval of 1848, they fail to explain the timing, simultaneity, or regional distribution of the events. Here a more economic perspective might be helpful. Many contemporary observers interpreted much of what was going on as a direct consequence of the serious shortfall in basic food supplies that had shaken the Continent in 1845-1847 and triggered famine and hunger riots throughout Europe, especially in Ireland, Flanders, and Silesia. ${ }^{4}$ A radical variant of this argument interprets the revolutions of 1848 in the broader context of class conflict-a view championed at the time by Karl Marx and Friedrich Engels, and later refined by Jürgen Kuczynski. ${ }^{5}$ However, this materialistic view is by no means confined to Marxist historiography. Another early proponent was Ernst Engel, the nineteenth-century Prussian statistician, who maintained that the economic crisis was what "triggered the bomb" in many parts of Europe. ${ }^{6}$ This strong emphasis on economic factors is also reflected in one strand of the Anglo-Saxon literature, ranging from W. W. Rostow, Eric Hobsbawm, and George Rudé to Charles, Louise, and Richard Tilly. ${ }^{7}$ It is supported by

\footnotetext{
${ }^{2}$ Issues at stake were the material deprivation of large parts of the rural population (pauperism) and state intervention in individual affairs, for instance, through military conscription and discretionary taxation. For an overview see Sperber, European Revolutions, pp. 47-49.

${ }^{3}$ We have systematically checked monographs and paper collections covering the 1848 revolutions in English, German, and Latin languages published since the mid-1990s for discussions of short-term socioeconomic developments such as the increase of food prices in 1845-1847 or the economic downturn of 1846-1848. Höbelt (1848) and Bruckmüller and Häusler (1848), who analyze the revolution in Austria, do not discuss economic factors at all. Neither do Schroeder (Transformation) nor Broers (Europe), nor the contributions on Hungary in Fischer (Ungarische Revolution). In the account of Judson (Wien) of the revolution in Austria socioeconomic factors are rarely mentioned. For Switzerland, the contributions in Hildbrand and Tanner (Zeichen) do not refer to economic factors. Some of the work on Switzerland collected in Ernst, Tanner, and Weishaupt (Revolution) does mention economic factors, but these are not found to be causal. Even in the abundant German anniversary literature the economic crisis is almost totally neglected. See Dipper and Speck, 1848; Dowe, Haupt, and Langewiesche, Europa 1848; Gall, 1848; Hardtwig, Revolution; Jansen and Mergel, Revolution; Lill, Revolution; Mommsen, 1848; Rill, 1848; Timmermann, 1848; and Langewiesche, Revolutionen. Notable exceptions are Sperber, European Revolutions; Hahn, "Sozioökonomische Ordnung"; Hein, Revolution; Lévêque, Ébranlement; and Stürmer, Crise. In contrast, earlier accounts of the 1848 revolutions analyzed long and short-term socioeconomic factors in great detail: see for example Stearns, Revolutions, pp. 11-35; C. Tilly et al., Rebellious Century; Siemann, Deutsche Revolution; Pinkney, Decisive Years; Wehler, Deutsche Gesellschaftsgeschichte, pp. 681f.; and Price, Revolutions, pp. 7, 24-26.

${ }^{4}$ Sigmann, 1848 , pp. 183-85.

${ }^{5}$ Kuczynski, "Wirtschaftliche und soziale Voraussetzungen."

${ }^{6}$ Engel, "Getreidepreise," p. 251 (our translation).

${ }^{7}$ Rostow, British Economy; Hobsbawm, "Economic Fluctuations"; Rudé, "Why Was There No Revolution?"; C. Tilly et al., Rebellious Century; and R. Tilly, Vom Zollverein. See also Stearns,
} 
a number of empirical studies of social disorder in the 1840s, which stress the importance of economic motives. ${ }^{8}$ For France, Ernest Labrousse explicitly linked the revolutions of 1789,1830 , and 1848 to changes in agricultural output and prices. ${ }^{9}$

We propose that it is precisely these economic crises that are most helpful in explaining the simultaneity and regional distribution of the European turmoil of 1848. In other words, even though ideas and institutions undoubtedly shaped the events in question, it was economic misery and the fear thereof that triggered them. This resurrection of the economic view of the 1848 revolutions is based on the high correlation between the geographic distribution of economic distress and political turbulence across Europe. In fact, after identifying the countries that suffered a significant food-supply shock in 1845-1847, and discussing evidence of a propagation mechanism that prolonged the crisis well into 1848 , we find that there is an almost perfect geographical match between economic crises and revolutionary activities. We also show that institutions, namely the existence or absence of a repressive political regime, while largely irrelevant to the occurrence of revolutionary activity, had a significant influence on the form such activity took: revolutions tended to be more violent if the regime was repressive.

The article proceeds as follows. We first investigate the size and significance of the grain-price shock that hit most European countries in the second half of the 1840s. To grasp the extent to which these shocks were indeed unexpected, we estimate the forecast errors of standard adaptive-expectations models for a data set encompassing grain prices for 27 countries between 1820 and 1850. It turns out that most European countries experienced a severe price shock in 1846 or 1847 . We then explore the propagation mechanism that extended the crisis well into 1848 , finding evidence that falling consumption and investment demand transformed the agricultural supply shock into a lagged demand shock to the manufacturing sector. We complete our argument by drawing a connection between political activity and its possible economic causes.

The economic view of the 1848 revolutions relies heavily on the occurrence of an antecedent crisis across Europe. But what defines an economic crisis? What sort of crisis will trigger political activism? And who will be the activists?

A possible starting point is the concept of revolution. Among the many definitions available, two characteristics stand out with respect to the revolutions of 1848: (i) the use of violence, or the credible threat thereof, in an

Revolutions, pp. 32-35; Price, Revolutions, pp. 17-22; and Sperber, European Revolutions, pp. 105-07.

${ }^{8}$ See for example R. Tilly, "Popular Disorders,” pp. 11-20; Bergmann, "Ökonomische Voraussetzungen" and Wirtschaftskrise; and Gailus, Straße.

${ }^{9}$ Labrousse, "1848." 
effort to change the political system; and (ii) collective action, that is, active involvement of "the crowd" in that effort. ${ }^{10}$ Accordingly, in what follows we will define a revolution either as widespread collective violence targeted at changing the political system, or as immediate and substantial constitutional reform implemented to prevent it. The potential or actual involvement of a large number of individuals has important consequences for our question here. Obviously, our understanding of why a revolution did or did not take place should not be based solely on an analysis of elites and their economic situation. While lawyers, publishers, journalists, doctors, and academics were undoubtedly important protagonists during the 1848 upheavals, they would not have been able to effect revolution on their own. It was the lower classes who provided the "muscle." Thus our focus must shift from the wellknown revolutionary protagonists to average men and women, especially in the capitals, where revolutionary activities were most pronounced. ${ }^{11}$

Economic distress is transformed into revolutionary action through the mediation of severe popular fear of a deteriorating socioeconomic situation. Hansjörg Siegenthaler has explained why and how economic discontent can reach a threshold that triggers political action. ${ }^{12}$ Under the conditions of the post-Napoleonic Restoration, this could only take the form of revolutionary activity in the sense defined above. The question is how to measure both the discontent and the threshold.

\section{AGRICULTURAL ORIGINS OF THE ECONOMIC CRISIS}

Households experience macroeconomic flux through changes in their real budgets. While this is as true today as it was during the first half of the nineteenth century, the channels through which an economic crisis would influence the family budget were different then. On the expenditure side, lower-class households around 1850 still spent between two-thirds and three-quarters of their incomes on nourishment. ${ }^{13}$ The bulk of the food purchased consisted of grain products and potatoes, which rendered household budgets very sensitive to changes in the prices of these goods. This sensitivity was greater the smaller the overall size of the budget, as low-income

\footnotetext{
${ }^{10}$ Kimmel, Revolution, pp. 4-7; and Goldstone, Revolution, pp. 7-12. We follow the broader definitions of Kimmel, which do not require that a revolution be successful. This broad definition is similar to the notion of revolution in C. Tilly ("Revolutions," pp. 519-24) and what he defined later as a "revolutionary situation" (European Revolutions, p. 10).

${ }^{11}$ Labrousse, “1848,” p. 77. Quote from Stearns, Revolutions, p. 12.

${ }^{12}$ Siegenthaler, Regelvertrauen, pp. 157-64.

${ }^{13}$ In England, 81 percent in 1790 and 78 percent in 1904-1913 (Phelps Brown and Hopkins, "Seven Centuries," p. 297); 63 percent in all households in Milan in 1847 (Maddalena, Prezzi, p. 330); 73 percent in Berlin in 1800 (Abel, Agrarkrisen, p. 245); and 59 percent among Prussian rural workers in 1847, 67 percent among urban workers in 1837 and 1847 (Saalfeld, "Lebensverhältnisse," pp. 236-39). Rural workers, of course, produced more of their own food than did urban workers.
} 


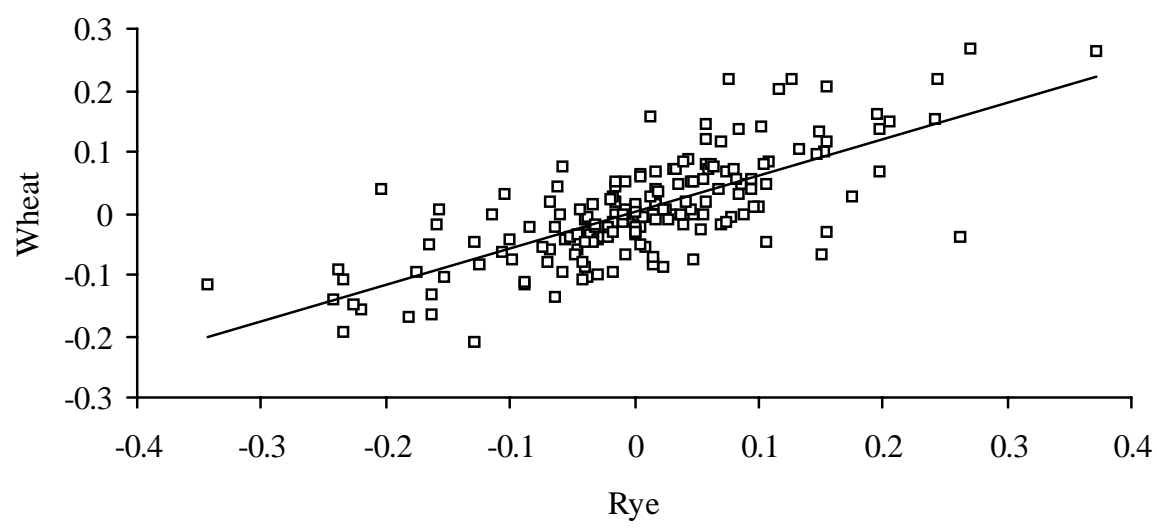

FIGURE 1

THE INTEGRATION OF PRUSSIAN GRAIN MARKETS, 1820-1850

Notes: Plotted are the annual first differences of the original price series, in logs. For illustrative purposes, we omit one outlier. The full (abbreviated) sample produces a highly significant coefficient of correlation of $0.77(0.73)$. Due to seasonality in rye and wheat prices, the coefficient for the raw data is much larger: 0.93 (full sample).

Source: Kopsidis, Marktintegration, table Vg/1 ff.

households tend to allocate more of their budgets to food (Engel's Law). ${ }^{14}$ In addition, the ability of households to protect their livelihood by substituting among foodstuffs was limited. For the period 1816-1850, the literature on Prussia reports correlation coefficients of 0.87 for wheat and rye prices, and 0.67 for wheat and potato prices. ${ }^{15}$ The tight integration of local grain markets in this period is illustrated by Figure 1, which plots bimonthly percentage changes in wheat prices over the previous year against a similar series for rye prices between 1820 and 1850 for the Prussian district of Arnsberg.

In principle, data on grain prices should allow us to obtain an idea of the time path of household expenditures prior to 1848. Getting a grip on the revenue side of household budgets is somewhat more difficult. On the one hand, it is well known that nominal industrial wages were fairly stable in the first half of the century. ${ }^{16}$ To the extent that this is a valid stylized fact, the easily accessible data on grain prices would also provide us with data on real wages, and thus on the purchasing power of fully employed wage laborers.

\footnotetext{
${ }^{14}$ According to Drame et al. (Siècle, p. 20), the price elasticity of demand for wheat hovered around 0.6 throughout nineteenth-century France.

${ }^{15}$ See Bass, Hungerkrisen, p. 62. Similar results for Cologne 1818-1850 are reported by Ebeling and Irsigler ("Zur Entwicklung," p. 306).

${ }^{16}$ For Germany see Gömmel, Realeinkommen, p. 27; and Gerhard, Löhne. For Belgium, France, and Great Britain see Mitchell, International Historical Statistics, p. 181.
} 

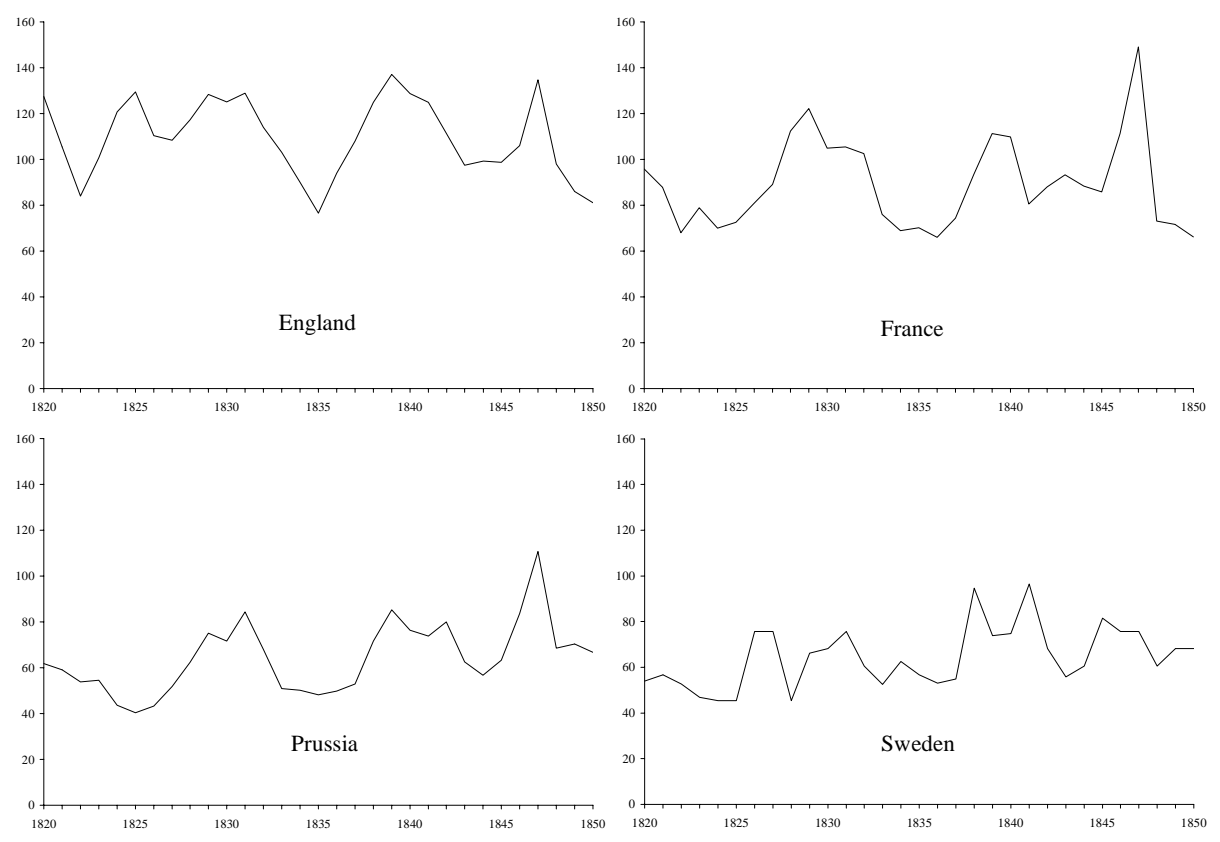

FIGURE 2

EUROPEAN WHEAT PRICES, 1820-1850

Notes: The series are for London, the region around Paris, Berlin, and Stockholm county. Sources: See the Appendix.

On the other hand, there is hardly any reliable information on effective working hours, which makes it almost impossible to compute a meaningful income series. ${ }^{17}$ A feasible solution, for nonagricultural employment at least, is to turn to Okun's Law to infer employment from the overall level of industrial activity. ${ }^{18}$ We have good reason to believe that this "law" was also valid for the nineteenth century (in fact, more so than today), and data on industrial production, at least at the sectoral level, are available for a number of countries.

Summing up, it seems possible to put together a sufficiently accurate picture of the economic well-being of households prior to the political turmoil that shook Europe around 1848. To that end we have assembled 27 grain-price series (see Appendix for details); four of them are presented in Figure 2. All series are for wheat prices, with the exception of Oldenburg and Russia (rye), and have been transformed into grams of fine silver per hectoliter, the classic unit in price history. ${ }^{19}$ Whenever possible, we have

\footnotetext{
${ }^{17}$ This point has been discussed by Hobsbawm, "Machine Breakers," p. 4.

${ }^{18}$ For a similar approach to the analysis of prerevolutionary France, see Weir, "Crises économiques," p. 938.

${ }^{19}$ See Braudel and Spooner, "Prices," p. 394. Abel (Agrarkrisen, pp. 290-95) used grams of silver per kilogram of wheat. In the first half of the nineteenth century, nearly all European currencies were still on silver or bimetallic standards.
} 


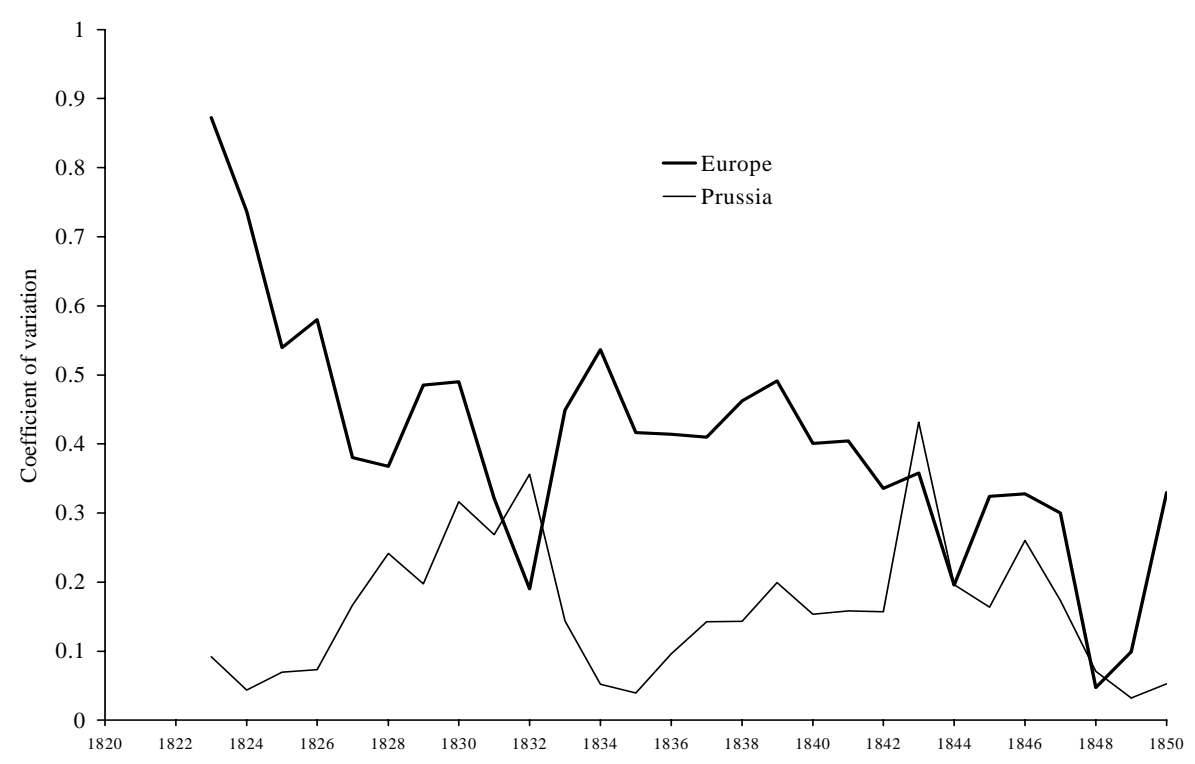

FIGURE 3

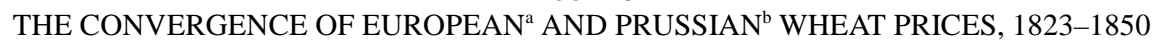

${ }^{\text {a }}$ Five groups of Continental countries: Southeast (Switzerland, Lombardy, Papal States, Austria, Hungary), West (France, Belgium), Center (Germany [aggregated], Netherlands), and North (Finland, Norway, Sweden). ${ }^{\mathrm{b}}$ Eight provinces.

Sources: See the Appendix; for Germany (aggregated) see Jacobs and Richter, Großhandelspreise, p. 74.

tried to gather data for the country's capital, the likely center of political activity. These differ only slightly from the national averages, however. ${ }^{20}$

Figure 2 reveals both similarities and variations across Europe. Whereas the price patterns in France and Prussia look very similar, the English and especially the Swedish experience look different. The English series shows the impact of the easing of the Corn Laws in 1842; and their final repeal in 1846 may help to explain the relative modesty of the increase in that year. Notwithstanding these and other idiosyncrasies, however, the series for France, Prussia, and England appear to share a number of regularities. One of them is a price spike - and thus, presumably, a blow to living standards for the majority of the population-during the period 1845-1847. This should not come as a surprise. There is evidence of a convergence of European grain markets by this time, due to cheaper land and sea transport. ${ }^{21}$ Figure 3 illustrates the phenomenon by comparing the coefficient of varia-

\footnotetext{
${ }^{20}$ For Austria, France, Prussia, and Sweden, where both national and capital series are available, the coefficient of correlation between both series is on average higher than 0.90 and never smaller than 0.80 . Some regional series show a somewhat larger standard deviation than do the national averages. Our results do not depend on the choice of the aggregation level, however. See the Appendix for details on the data.

${ }^{21}$ For the impact of the Corn Laws on British wheat prices and European wheat-price convergence, see Williamson, “Impact," pp. 124-29.
} 
tion among different regions of Prussia with the coefficient of variation among five areas of continental Europe. Despite its large territory and different climatic zones, Prussia can be regarded as a fairly well integrated economic area in this period. ${ }^{22}$ Compared with this benchmark, the prolonged period of pan-European convergence is quite remarkable: starting at levels four times higher, by the 1840s the regions had reached roughly comparable levels of market integration.

But there are also discrepancies in the time paths portrayed in Figure 2. While in France and Prussia the years 1845-1847 are marked by a dramatic increase in grain prices, the price movements in England and Sweden in these years do not stand out as particularly irregular. This discrepancy may be important. Consider a household that, based on past experience, takes the precautions necessary to insure itself against "regular"- and thus in principle foreseeable-fluctuations in the cost of living. Clearly, as long as a price increase stays within the expected range, we would not expect an extraordinary political reaction. If, however, an exceptional price "shock" severely and unexpectedly diminished the real budget of a large part of the population, such a backlash seems much more likely.

The argument lends itself to a more formal exposition. We can picture households at any given time $t$ as forming expectations about the cost of living at time $t+1$ based on an adaptive expectations model

$$
p_{t+1}^{e}=\hat{\alpha}_{t}+\sum_{j=0}^{n} \hat{\delta}_{t, j} p_{t-j}
$$

where $p^{e}$ and $p$ are expected and actual food prices and the lag length $n$ is assumed to be constant. The time-dependent parameters $\hat{\alpha}$ and $\hat{\delta}$ are OLS coefficients from an autoregressive (AR) model estimated with the present and past observations on $p$ available at time $t$

$$
p_{t}=\alpha+\sum_{j=0}^{n} \delta_{j} p_{t-1-j}+\varepsilon_{t}
$$

where $\varepsilon$ is a random variable following standard assumptions. That is, households update their estimates for $\hat{\alpha}$ and $\hat{\delta}$ in every period $t$ to produce the best available forecast about $p_{t+1}^{e}$, the following period's price level. But the forecast will not be perfect. We can then define a price "shock"- a highly unanticipated and irregular price movement in the sense introduced earlier - as a significant (scaled) ex-post forecast error

$$
e_{t+1}=\frac{p_{t+1}-p_{t+1}^{e}}{\theta(\cdot)}
$$

${ }^{22}$ Fremdling and Hohorst, "Marktintegration," pp. 100f. 
where $\theta$ is a scaling factor that increases in the sample length $t$ and the $(1 \mathrm{x} \mathrm{n})$ vector of observations on $p$ used to forecast $p_{t+1}, \mathbf{p}_{t+1}$. If we define

$$
\theta \equiv\left[1+\mathbf{p}_{t+1}^{\prime}\left(\mathbf{P}_{t}^{\prime} \mathbf{P}_{t}\right)^{-1} \mathbf{p}_{t+1}\right]^{1 / 2}
$$

with $\mathbf{P}_{t}$ being the $(t \times n)$ matrix of observations used to forecast $p$ in all previous periods $(n+1, \ldots, t), e_{t+1}$ is just the standard recursive residual from Equation $2 .^{23}$ As

$$
e_{t+1} \sim N\left[0, \sigma_{\varepsilon}^{2}\right]
$$

a significant deviation of the scaled forecast error from zero indicates both a "shock" in the sense defined above and a structural break in the model.

Computing the scaled forecast errors $e_{t+1}$ for our set of 27 countries is a straightforward exercise once the lag length $n$ is determined. We set $n=5$ for each country, which allows the AR process-and, thus, the predictors-to cover both cyclical and acyclical regularities in the time series. ${ }^{24}$ The majority of the series run from 1820 to 1850 ; with the exception of Finland, all are stationary. ${ }^{25}$ Figure 4 presents, for the four countries already selected for Figure 2, computed forecast errors and the respective twostandard-error bands. The interpretation of this figure is fairly easy. If at any point in time the chart line deviates positively (negatively) from zero, the actual price level at this point exceeded (fell short of) the estimated expectations of households. If a deviation is greater than twice the standard error of the model used to compute the forecast - that is, if it breaches one of the dotted boundaries - we regard the shock as significant.

Before we move on, a brief discussion of the threshold dividing "normal flux" and "shocks" is called for. Our two-standard-error criterion is purely statistical, building on the conventional notion of statistical significance. From a strictly historical perspective this might seem somewhat arbitrary. However, the statistical criterion does not seem unreasonable; indeed, it very closely approximates other plausible threshold criteria. For instance, simply focusing on the number of pre-revolutionary years in which grain prices were above their average value leads to a very similar profile of shocks across countries.

\footnotetext{
${ }^{23}$ See for example Greene, Econometric Analysis, pp. $216 \mathrm{f}$.

${ }^{24}$ Price cycles were well known to contemporaries. They are also quite obvious in the present data. For evidence on cycles in grain prices see for instance Bauernfeind and Woitek, "Agrarian Cycles."

${ }^{25}$ Based on standard ADF tests. The price series for Baden, Hesse, Saxony, Sweden, and Wurttemberg are only stationary around a trend. However, recalculating the AR models with difference-filtered data or introducing a trend into the estimated model does not change the results. The same is true for the Finnish series. Only Hesse remains a borderline case. The complete data set (grain prices as well as computed forecast errors) for the sample is available on request.
} 


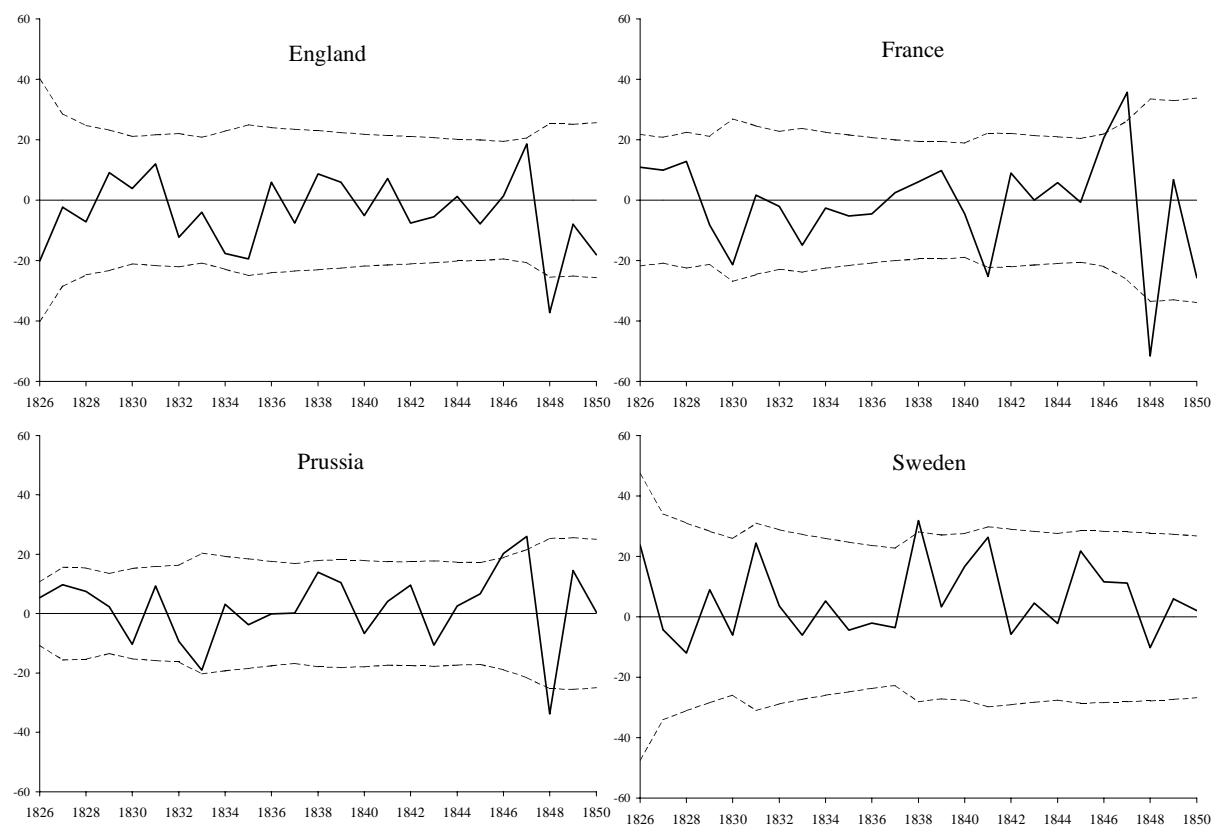

FIGURE 4

FORECAST GRAIN-PRICE ERRORS, 1826-1850

Sources: See the Appendix.

Note also that the two-standard-error criterion of the forecast model leads to very robust results: any other threshold value in an interval of \pm 0.18 around 2 produces the very same distribution of pre-1848 shocks among the countries in our sample (see Table 3, column 3). ${ }^{26}$ We will return to this issue.

In the event, using the two-standard-error criterion yields results that are very much in line with those displayed in Figure 2. While the panels for both France and Prussia feature a significant positive price shock in 1846/47 (as well as a corresponding negative shock as prices returned to normal in 1848), those for England and Sweden do not. The reason for this is that even though the latter countries experienced higher prices prior to 1848 , these increases stayed within the confines of the normal ups and downs of the cost of living. This is obvious in the case of Sweden, but it is also true for England, where only the fall in prices after the good harvest of 1847 qualifies as a shock relative to expectations-albeit a positive one. ${ }^{27}$

From Figure 4-and from similar figures for the other 23 countries in our sample $^{28}$ - it follows that a number of European countries did indeed suffer

\footnotetext{
${ }^{26}$ Such a rule does, however, ignore the role that price expectations might have played in the accumulation of buffer stocks and, ultimately, in the impact of the agrarian crisis on households.

${ }^{27}$ Ireland (for which we do not have comparable data) was a very different case. For a comparable approach see Solar, "Great Famine," pp. 114-18.

${ }^{28}$ All figures are available on request.
} 
a significant cost-of-living shock just prior to 1848 . It is tempting to jump ahead and compare the regional distribution of these findings with the occurrence of political turbulence. But there is a problem of timing. Despite some variance in the onset of the various grain-price shocks, in virtually every case the year 1848 itself was characterized by sizable price decreases, not increases. To some extent this might be an artifact of the frequency of the data. To see whether this is the case, Figure 5 shows monthly wheat prices for the region around Paris and for Berlin. In both cases, wheat prices were at a low level at the beginning of 1845 . The price increase which followed accelerated in mid-1845, paused briefly around the turn of 1846, and then resumed with a vengeance into the summer of 1847, when a third consecutive bad harvest was expected all over Europe. ${ }^{29}$ Thus, what consumers experienced in both countries was far more than a "blip": it was a seemingly incessant price increase over two-and-a-half years. Moreover, although prices fell after mid-1847, through the end of that year they remained above the average for $1838-1845 .{ }^{30}$ Still, by the time political unrest started to spread across Europe in early 1848 , the cost of living had definitely moderated in both regions. Even in Berlin, where prices were on the rise again later in the year, the surprisingly good harvests of 1847 helped household expenditures to regain their average levels during the first half of 1848 .

To some extent, the time lag between the peak of the food-price increase (and the subsistence crisis it caused) and the political unrest is not totally unexpected. The reason is that people who face starvation are physically weak and focused on survival. It is only after they have regained their physical forces and digested their recent trauma that they start to (re)act politically. ${ }^{31}$ From this perspective, the time lag is unsurprising. But there is an additional economic link between the two events.

\section{PROPAGATION OF THE CRISIS TO THE INDUSTRIAL SECTOR, 1847-1848}

In fact, one of the reasons why so many contemporary observers insisted on a close connection between the agricultural crisis and the revolutions was the former's lagged propagation into other sectors of the economy. ${ }^{32}$ In this age, all the world's economies were still greatly influenced by fluctuations in agriculture. With a majority of households earning close to the subsistence level, costlier foodstuffs translated into lower demand for all

\footnotetext{
${ }^{29}$ Boot, Commercial Crisis, p. 66.

${ }^{30}$ The dominant agrarian cycle has a length of eight years. See Bauernfeind and Woitek, "Agrarian Cycles."

${ }^{31}$ Stearns, Revolutions, p. 34; see also Tocqueville, Ancien régime, p. 219.

${ }^{32}$ See for example Roscher, Über Kornhandel, pp. 61-65.
} 

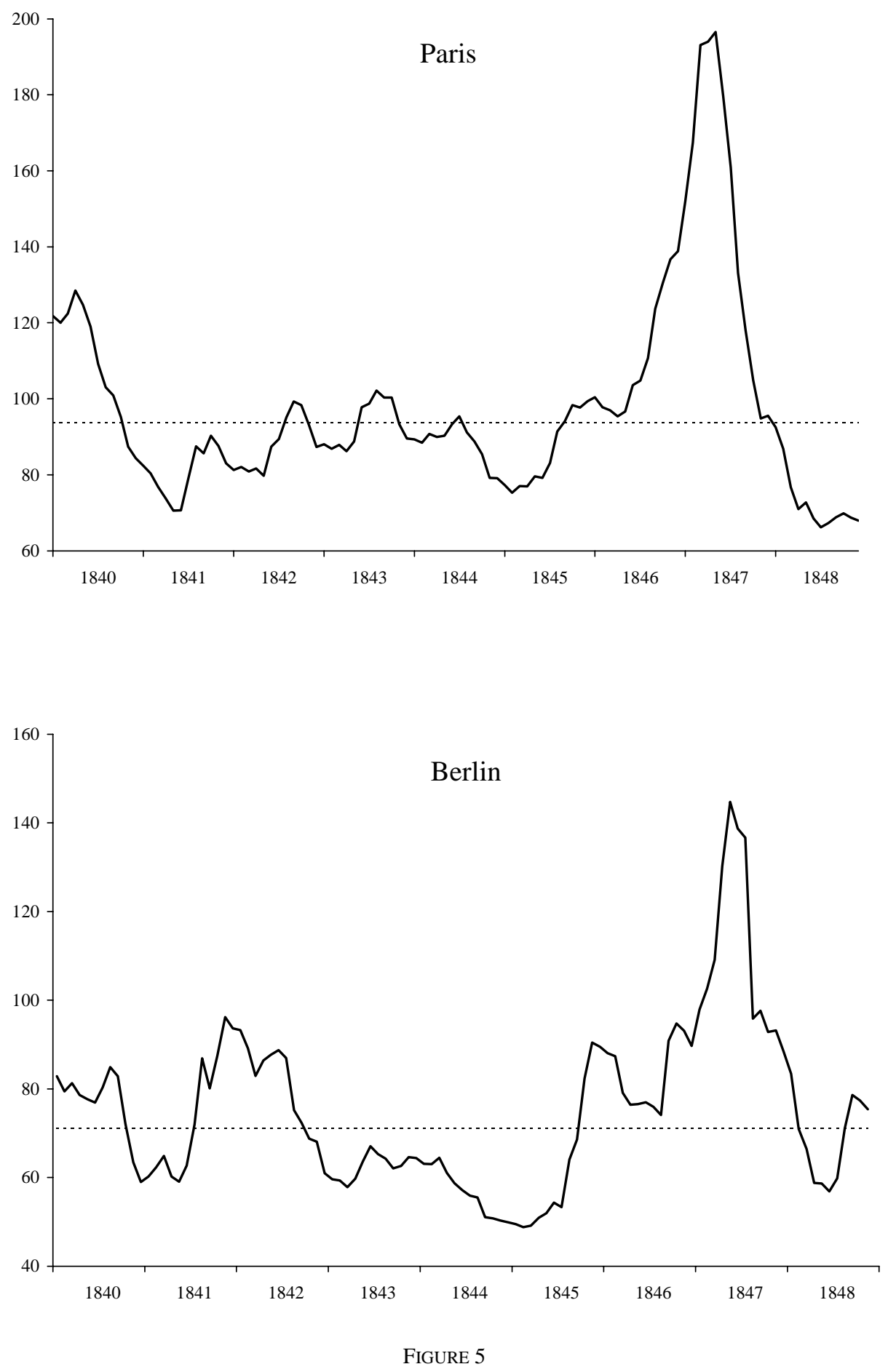

MONTHLY WHEAT PRICES IN PARIS AND BERLIN, 1840-1848

Notes: The dotted lines mark the average wheat price 1838-1845.

Sources: Amtsblatt 1840-1849; Labrousse, Romano, and Dreyfus, Prix, p. $196 f$. 
other goods, notably manufactures. ${ }^{33}$ The translation would not have been immediate, as some households ran down their savings in an attempt to smooth consumption. However, it seems plausible to presume that lower household demand (the consumption channel) and, consequently, reduced investment demand (the investment channel) would eventually turn an agricultural crisis into an industrial crisis as well.

Let us first discuss how the food crisis influenced business attitudes and investment behavior. During a negative food-supply shock, purchasing power is shifted from (net) food consumers to (net) food producers. As nutritional status declines toward-or even falls below-the subsistence level, demand becomes price-inelastic. This was the case in 1845-1847, when net food consumers, especially the urban lower and middle classes, were forced to reduce their rate of saving and run down their financial assets. ${ }^{34}$ While their savings fell, savings by net food producers presumably increased; but since food producers will have spent at least some of their windfall on purchases of other goods, the overall effect of the price increase on credit demand must have been positive. Under the rules of the various specie standards, by contrast, credit supply must have contracted. England, for instance, experienced a gold drain as grain imports soared and her trade balance turned negative, thus inducing a contraction of the money supply. ${ }^{35}$ A third factor in the tightening of credit was misspeculation. In mid-1847, as harvest forecasts switched from gloomy to optimistic and massive corn imports from Russia and the United States were reaching the markets, prices plummeted and many traders found themselves in desperate need of credit. This further increased interest rates all over Europe. ${ }^{36}$ In fact, the available data underestimate the strain put on borrowers, because most interest-rate series are regulated bank rates which were not always adjusted to market conditions. As a result, borrowers were often subject to credit rationing. ${ }^{37}$

\footnotetext{
${ }^{33}$ For France see Labrousse ("Panoramas"), who relies on monthly data, and the simulations of LévyLeboyer and Bourguignon (French Economy, pp. 227-31), which show a time lag of one year. For the Prussian textile industry see Blumberg (Deutsche Textilindustrie, pp. 200-05, 382), who uses quarterly data. For the general crisis of crafts in 1847-1848 see Kuczynski, Lage, pp. 1.178f., 2.85-97; and Bergmann, Wirtschaftskrise, pp. 50, 63-70.

${ }^{34}$ See for instance Obermann, "Wirtschafts- und sozialpolitische Aspekte," for evidence on dissaving in Prussian lower- and middle-class households.

${ }^{35}$ Described in detail by Boot, Commercial Crisis, ch. 6. See also Ward-Perkins, "Commercial Crisis."

${ }^{36}$ For monthly London market and bank rates see Ward-Perkins, "Commercial Crisis," p. 94. For annual series of short-term European interest rates see Homer, History, pp. 208, 230, 242, 252, 265, and 270.

${ }^{37}$ For England see Boot, Commercial Crisis, p. 49; for Prussia see Obermann, "Wirtschafts- und sozialpolitische Aspekte,” p. 163, and Lichter, Preußische Notenbankpolitik, p. 22. In England, the commercial crisis was immediately overcome when the Bank of England was allowed to lend at a bank rate above 8 percent. See Ward-Perkins, "Commercial Crisis," p. 78; and Boot, Commercial Crisis, p. 52 .
} 
While most of the available European interest-rate series show a local maximum in 1847, the impact of tighter financial conditions on investment was felt as early as the second half of 1846 and, due to the planning lags involved in investment demand, well into 1848. Even though empirical analysis supporting this view is seriously hampered by the quality of the interestrate data, it seems to be in line with the available anecdotal evidence. ${ }^{38}$ For instance, we know that numerous firms failed between mid-1846 and the end of 1848, especially in the textile sector, and that contemporaries saw lack of credit as one of the main culprits. ${ }^{39}$ The visible slowdown in railway-track investment in France, Germany, and (to a somewhat lesser extent) England also points in that direction. The profitability of the (mostly private) German railway companies dropped during the crisis, and eventually investment was scaled back to meet the financing constraints. By contrast, most French railways had been nationalized; here it was lack of public funds due to the food crisis which made the government cancel railway investment programs. In both countries, this seriously affected the metals and mining sectors from spring 1847 through the end of $1848 .{ }^{40}$ In sum, it would seem that the deterioration of financial conditions in the wake of the agrarian crisis of 1845-1847 had a sizable lagged impact on firm failures and investment behavior, which transmitted the crisis across sectors and into the critical year 1848 .

Turning from the investment to the consumption channel, we can apply a somewhat more direct test for the existence of a propagation mechanism. Although there are no reliable data on household demand for manufactured goods, it seems reasonable to rely on grain prices as a proxy for the changes in household demand. The question to be addressed is whether there is evidence for a lagged propagation of the grain crisis into manufacturing and possibly, following Okun's Law, on to employment. As a first step, we subject the data at hand to a standard Granger causality test. In a nutshell, the test asks how much of the growth path of, say, French manufacturing output can be explained by lagged values of French grain prices, and viceversa. ${ }^{41}$ In both cases the possible determinants are added to an AR model of the endogenous variable. Causality in the sense of the test should be interpreted conservatively. For instance, rejection of the null hypothesis of "no causality" in the case of lagged grain prices influencing production

\footnotetext{
${ }^{38}$ We comment on selected econometric results in note 44 below.

${ }^{39}$ See for example Labrousse, "Panoramas," pp. viii-x; Obermann, "Wirtschafts- und sozialpolitische Aspekte," pp. 162-67; and Wehler, Deutsche Gesellschaftsgeschichte, pp. 648-52.

${ }^{40}$ See Labrousse, "1848" and "Panoramas"; and Spree and Bergmann, "Konjunkturelle Entwicklung," pp. 314-21. The growth of the German rail network did not accelerate again before the 1850s. Ward-Perkins ("Commercial Crisis," p. 87) and Boot (Commercial Crisis, pp. 20, 81) point out that continued railway investment stabilized the UK economy by late 1847 .

${ }^{41}$ For the calculations in Table 1, we use the price data described in the Appendix. Replacing the price data for capital cities by national averages leads to only very slight deviations. The same is true for the regression results in Table 2.
} 
TABLE 1 GRANGER TESTS OF CAUSALITY, 1820-1850

\begin{tabular}{lllllll}
\hline \hline Country & \multicolumn{1}{c}{ Direction } & Lag 1 & Lag 2 & Lag 3 & Lag 4 & Lag 5 \\
\hline Austria & Grain Prices $\rightarrow$ Manufacturing & 0.05 & 0.07 & 0.12 & 0.08 & 0.14 \\
& Manufacturing $\rightarrow$ Grain Prices & 0.70 & 0.45 & 0.70 & 0.89 & 0.86 \\
England & Grain Prices $\rightarrow$ Manufacturing & 0.13 & 0.07 & 0.09 & $0.05^{*}$ & 0.10 \\
& Manufacturing $\rightarrow$ Grain Prices & 0.55 & 0.89 & 0.12 & 0.20 & 0.36 \\
France & Grain Prices $\rightarrow$ Manufacturing & 0.06 & $0.01^{*}$ & $0.01^{*}$ & 0.06 & 0.17 \\
& Manufacturing $\rightarrow$ Grain Prices & 0.28 & 0.50 & 0.61 & 0.89 & 0.66 \\
Hungary & Grain Prices $\rightarrow$ Manufacturing & $0.01^{*}$ & $0.00^{*}$ & $0.03^{*}$ & $0.02^{*}$ & 0.15 \\
& Manufacturing $\rightarrow$ Grain Prices & 0.17 & 0.06 & 0.08 & 0.08 & 0.13 \\
Netherlands & Grain Prices $\rightarrow$ Manufacturing & 0.14 & 0.24 & 0.18 & 0.16 & 0.20 \\
& Manufacturing $\rightarrow$ Grain Prices & 0.40 & 0.74 & 0.40 & 0.34 & 0.37 \\
Prussia & Grain Prices $\rightarrow$ Manufacturing & $0.03^{*}$ & $0.00^{*}$ & $0.01^{*}$ & 0.06 & $0.03^{*}$ \\
& Manufacturing $\rightarrow$ Grain Prices & 0.77 & 0.43 & 0.44 & 0.15 & 0.23 \\
Sweden & Grain Prices $\rightarrow$ Manufacturing & $0.00^{*}$ & 0.00 & $0.00^{*}$ & $0.01 *$ & $0.02^{*}$ \\
& Manufacturing $\rightarrow$ Grain Prices & 0.20 & 0.44 & 0.61 & 0.46 & 0.13 \\
\hline
\end{tabular}

a Textile production only.

Notes: $\mathrm{P}(F$-stat $)$ for Granger tests at different lag lengths. All data are annual; grain prices are in levels, production data are in growth rates computed as first differences of the raw data in logs. Asterisks indicate rejection of H0 ("no causality" at conventional levels). Granger causality is commonly interpreted as meaning that the "causal"series precedes the other series and contains information useful in predicting it.

Sources: See the Appendix.

would suggest that the former series precedes the latter and helps in forecasting it. Table 1 presents our results. The model is symmetrical: the first row reports the number of lags for the AR process, as well as the number of lagged exogenous variables included. The period under consideration is again 1820-1850.

The main message of Table 1 is that grain prices are indeed Grangercausal for manufacturing in some countries, but the converse fails to hold for any single country. The results for Austria and the Netherlands are somewhat weak, but still suggestive. The results for England fall in the same category, but here we should not be surprised given England's leading role in the process of industrialization. In general, the evidence clearly suggests that changes in grain prices preceded changes in the growth rate of nonagricultural activity. The results lend credibility to our claim that the economic crisis of $1845-1847$, initiated by bad harvests, extended into 1848 by triggering a crisis in the manufacturing sector. Or did it? After all, the existence of Granger-causality between grain prices and manufacturing does not necessarily imply that a significant shock (in the sense defined above) to the former series also caused a significant shock to the latter.

In order to see whether there are significant shocks in the available production data following significant shocks in grain prices, we again make use of the method established above. Figure 6 presents forecast errors (from a model similar to equation 2) for the data used in Table 1. Again, we set the 

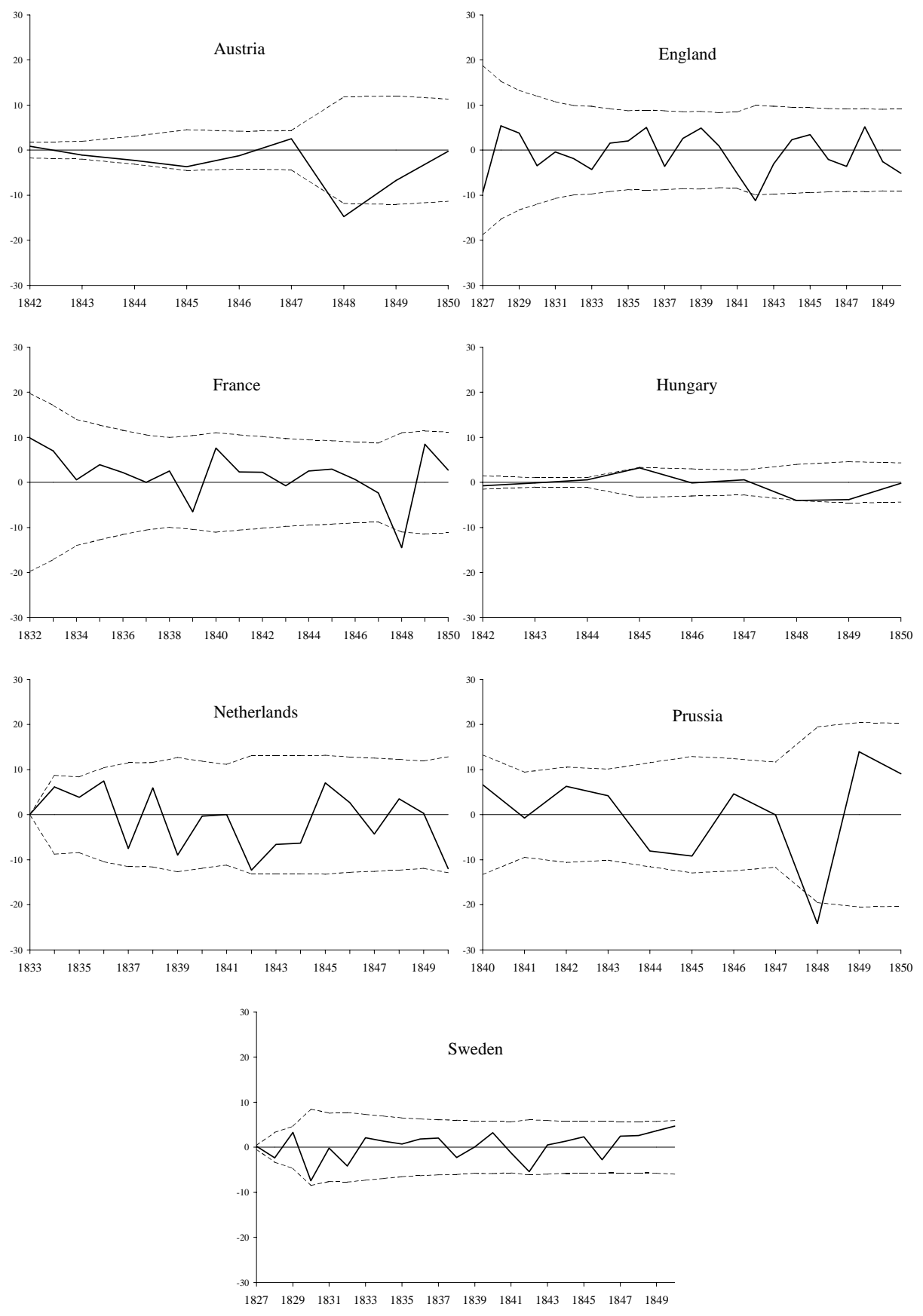

FIGURE 6

INDUSTRIAL SHOCKS, 1827-1850

Notes: All growth rates in percent. Prussia: textile production only. Netherlands: model includes trend. Sources: See the Appendix. 
lag of the AR part uniformly to $n=5$ across all countries, even though some of the data series are rather short: the French, Prussian, and Habsburg series start only in 1820,1828 , and 1830 , respectively. The remaining series, however, run from 1815 to $1850 .{ }^{42}$

Austria, France, Hungary, and Prussia show significant negative shocks to manufacturing in 1848, whereas England and Sweden, which were also spared a shock in grain prices, do not. The anomaly is the Netherlands, which experienced a grain-price shock but no manufacturing shock. Otherwise we find that all countries included in the manufacturing data set that were hit by (spared) a significant grain-price shock in $1846 / 47$ also found themselves suffering (exempt) from a significant industrial recession in $1848 .^{43}$

Even though Figure 6 adds considerably to the evidence produced by the Granger tests, there are still reasons why the propagation argument might not yet be convincing. First, the manufacturing data could themselves be influenced by the revolutionary activity of 1848 . After all, workers protesting in the streets are not at their workbenches. Second, statistical significance does not guarantee that the strength of the connection between the agricultural and manufacturing sectors was sufficient to explain the downturn in production. Describing the correlation between the variables using a simple multivariate regression model addresses both problems. Our exercise includes England, France, Prussia, the Habsburg countries, the Netherlands, and Sweden. We estimate two variants of the following equation

$$
\hat{y}_{t}=\alpha+\sum_{i=1}^{m} \beta_{i} \hat{y}_{t-i}+\delta p_{t-1}+\lambda 1848_{t}+\varepsilon_{t}
$$

Equation 6 basically describes an AR model with an added structural component, where $\hat{y}$ is the growth rate in manufacturing (in percent), $p$ is the price of grain (in grams of fine silver per hectoliter), and 1848 is a dummy variable that equals one in the year 1848 and zero otherwise. ${ }^{44}$ The discussion of Granger causality suggests that grain prices enter with a lag. The dummy variable takes account of the possibility that the industrial crisis

\footnotetext{
${ }^{42}$ All series are stationary according to standard ADF tests. In the case of the Netherlands the series is stationary around a trend. The results are robust with regard to changes in the lag length of the AR model used to compute the forecasts and standard errors.

${ }^{43}$ Again the statistical rule identifying "shocks" is quite robust. Table 3 reveals that lower thresholds for the forecast errors work equally well. See also note 51. Figures for all countries are available on request.

${ }^{44}$ We use $m=4$ to economize on degrees of freedom. We have also experimented with one-period lagged nominal and real interest rates as explanatory variables for England, France, and Prussia. Where significant, interest rates had a negative impact on output growth. The results with regard to grain prices and the revolution dummy were similar to the results presented in Table 2. Additional results are available on request.
} 
TABLE 2

DETERMINANTS OF MANUFACTURING GROWTH RATES

(see equation 6)

\begin{tabular}{|c|c|c|c|c|c|c|c|c|c|c|c|c|c|c|}
\hline & \multicolumn{2}{|c|}{ Austria } & \multicolumn{2}{|c|}{ England } & \multicolumn{2}{|c|}{ France } & \multicolumn{2}{|c|}{ Hungary } & \multicolumn{2}{|c|}{ Netherlands } & \multicolumn{2}{|c|}{ Prussia $^{a}$} & \multicolumn{2}{|c|}{ Sweden } \\
\hline & (i) & (ii) & (i) & (ii) & (i) & (ii) & (i) & (ii) & (i) & (ii) & (i) & (ii) & (i) & (ii) \\
\hline$\alpha$ & $\begin{array}{l}21.19 * * * \\
(6.33)\end{array}$ & $\begin{array}{c}13.99 * \\
(2.25)\end{array}$ & $\begin{array}{l}13.54 * * \\
(2.31)\end{array}$ & $\begin{array}{l}15.42^{* *} \\
(2.65)\end{array}$ & $\begin{array}{c}9.58 \\
(1.52)\end{array}$ & $\begin{array}{c}5.54 \\
(0.83)\end{array}$ & $\begin{array}{l}4.20 * * * \\
(3.79)\end{array}$ & $\begin{array}{c}0.66 \\
(0.24)\end{array}$ & $\begin{array}{c}7.74 \\
(1.07)\end{array}$ & $\begin{array}{c}8.81 \\
(1.10)\end{array}$ & $\begin{array}{l}31.78 * * * \\
(3.91)\end{array}$ & $\begin{array}{l}23.18^{* *} \\
(2.49)\end{array}$ & $\begin{array}{l}10.87 * * * \\
(3.70)\end{array}$ & $\begin{array}{l}11.05^{* * * *} \\
(3.48)\end{array}$ \\
\hline$y$ & -0.94 & -0.92 & -0.61 & -0.54 & -0.51 & -0.45 & -0.18 & -0.11 & -0.39 & -0.38 & -0.70 & -0.65 & -0.68 & -0.71 \\
\hline $\begin{array}{l}t-1 \\
y-8\end{array}$ & -0.80 & -0.56 & -0.62 & -0.59 & -0.68 & -0.48 & 0.58 & -0.58 & -0.14 & -0.15 & -0.76 & -0.64 & -0.34 & -0.31 \\
\hline$y^{t-2}$ & -0.63 & -0.53 & -0.27 & -0.31 & -0.18 & -0.05 & 0.54 & 1.26 & -0.18 & -0.20 & -0.09 & -0.13 & -0.37 & -0.39 \\
\hline$t_{t-4}^{t-8}$ & -0.33 & -0.28 & -0.32 & -0.43 & -0.39 & -0.33 & -0.21 & 0.20 & -0.20 & 0.18 & 0.18 & 0.09 & -0.16 & -0.19 \\
\hline$p_{t-1}^{t-4}$ & $\begin{array}{l}-0.22 * * * \\
(4.81)\end{array}$ & $\begin{array}{c}-0.11 \\
(1.10)\end{array}$ & $\begin{array}{c}-0.07 \\
(1.65)\end{array}$ & $\begin{array}{l}-0.09 * * \\
(2.18)\end{array}$ & $\begin{array}{l}-0.16^{* * * *} \\
(3.59)\end{array}$ & $\begin{array}{c}-0.08^{*} \\
(1.80)\end{array}$ & $\begin{array}{l}-0.09 * * * \\
(3.37)\end{array}$ & $\begin{array}{c}-0.04 \\
(1.11)\end{array}$ & $\begin{array}{c}-0.06 \\
(0.95)\end{array}$ & $\begin{array}{c}-0.07 \\
(0.92)\end{array}$ & $\begin{array}{l}-0.42^{* * * *} \\
(4.11)\end{array}$ & $\begin{array}{c}-0.29 * * \\
(2.49)\end{array}$ & $\begin{array}{l}-0.14 * * * \\
(3.07)\end{array}$ & $\begin{array}{l}-0.15^{* * * *} \\
(2.86)\end{array}$ \\
\hline $1848_{t}$ & & $\begin{array}{c}-9.82 \\
(1.63)\end{array}$ & & $\begin{array}{l}10.49 * * * \\
(3.17)\end{array}$ & & $\begin{array}{c}-12.38 * * * \\
(3.71)\end{array}$ & & $\begin{array}{c}-6.55^{*} \\
(1.88)\end{array}$ & & $\begin{array}{c}4.01 \\
(0.58)\end{array}$ & & $\begin{array}{c}-13.08^{* *} \\
(2.77)\end{array}$ & & $\begin{array}{c}2.22 \\
(1.29)\end{array}$ \\
\hline Period & $1835-50$ & $1835-50$ & $1820-50$ & $1820-50$ & $1825-50$ & $1825-50$ & $1835-50$ & $1835-50$ & $1820-50$ & $1820-50$ & $1833-50$ & $1833-50$ & $1820-50$ & $1820-50$ \\
\hline$R^{2}$ (adj.) & 0.64 & 0.66 & 0.28 & 0.36 & 0.39 & 0.64 & 0.46 & 0.53 & 0.18 & 0.15 & 0.57 & 0.59 & 0.49 & 0.48 \\
\hline
\end{tabular}

$*$ Significant at the 10 percent level.

$* *$ Significant at the 5 percent level.

$* * *=$ Significant at the 1 percent level.

${ }^{\text {a }}$ Textile production only.

Notes: HAC $t$-statistics (absolute) are in parentheses. In all cases the $\mathrm{AR}(\mathrm{m}=4)$ elements of the models are jointly significant at conventional levels (Wald $F$-test). $Q$-tests (at lag 1 and larger) suggest no autocorrelation of the residuals. The models for England, France, the Netherlands, and Sweden include a linear and a quadratic trend term (not reported).

Sources: See the Appendix. 
of 1848 might have been a consequence of the revolution, not of the agricultural supply shock. Table 2 presents OLS estimates of equation 6.

Let us first consider columns (i), which exclude the time dummy. From what has been said about the channels linking agriculture with manufacturing, we should expect the grain-price coefficients to be negative and significant. And indeed, the sign of the impact of grain prices is as anticipated in all cases, and lacks statistical significance at conventional levels only in the cases of England (the industrial leader) and the Netherlands.

Considering that some of the time series are rather short, the performance of the consumption channel is quite robust with regard to the introduction of the 1848 dummy variable (columns (ii)). The dummy has at least a marginally significant negative impact for France, Hungary, and Prussia, while the impact in England (which did not have a revolution) is significantly positive. In the cases of Austria, the Netherlands, and Sweden, the dummy remains insignificant. But while the revolutions played some role in shaping manufacturing activity, an important part of the explanation of the slump in production in 1848 obviously still derives from lagged grain prices. The negative sign on $p_{t-1}$ remains unchanged across countries and, with the exception of Austria and Hungary, at least marginally significant. In the case of England the grain-price variable actually gains in significance after the introduction of 1848. The results for the Dutch data remain unchanged. ${ }^{45}$

What was the quantitative impact of the 1847 grain crisis on manufacturing? Take for instance Prussia and France, which display a significant coefficient on $p_{t-1}$ in both columns. Grain prices in Prussia (France) increased by 27.12 (37.85) grams of fine silver from 1846 to 1847 . Based on the estimated coefficients in Table 2, Columns (ii), this translated into a decrease in 1848 manufacturing output of 7.86 (3.03) percentage points or 32.67 (23.03) percent of the actual decline. According to Columns (i), the decline explained by the grain crisis is even larger (47.31 and 46.06 percent, respectively). In England, the negative impact of the agricultural price increase on industrial expansion remained in the two-percentage-point range-too low, that is, to force an overall decline in real activity. We can conclude that the quantitative impact of the grain crisis on the industrial sector was considerable in France, Prussia, and the Habsburg countries, but not in more highly industrialized England.

\section{CRISIS AND REVOLUTION}

So far we have established the existence of a regional pattern of significant shocks to grain prices - and, thus, to the cost of living in a number of

\footnotetext{
${ }^{45}$ Note that to the extent that the revolution is in fact endogenous to the economic crisis, we should rely on a model excluding the 1848 dummy.
} 
European countries-between 1845 and 1847; we then linked the grain crisis to the manufacturing sector, which helps explain the propagation of the initial shock into 1848. But we still have to connect our economic findings with the political data.

It is not altogether straightforward to determine whether a given country experienced a revolution or not. For the non-German countries we follow the consensus in the literature, according to which France, the Italian states, Switzerland, Austria, Bohemia, and Hungary experienced widespread political violence and thus, clearly, revolutions in any sense of the word. In the broader sense defined above, Belgium, Denmark, and the Netherlands, which were able to avoid widespread violence only by undertaking preemptive constitutional reform, also qualify as revolutionary situations. ${ }^{46}$ By contrast, the other Scandinavian states, England, Russia, and Spain neither experienced widespread political violence, nor saw their governments forced to change the constitution significantly. For Ireland, which experienced severe agrarian crime but arguably no revolutionary action, we could not find reliable grain-price data for our sample period. ${ }^{47}$

For the German states, evaluation is much more difficult. The German historiography of 1848 has long been determined by the Prussia-centered perspective of German unification. But in the 1840s the German states were fully independent entities with quite different political paths, some with constitutions (as in southern Germany), others absolutist and more or less repressive (such as Prussia). Unlike Europe as a whole, the German states in our sample can be classed into only two groups. Widespread violence occurred in Baden, Bavaria, Hamburg, Hesse-Darmstadt, MecklenburgSchwerin, Prussia, Saxony, and Württemberg; preemptive constitutional concessions occurred in Bremen, Brunswick, and Oldenburg. Not one of them failed to experience either political violence or preemptive reform. ${ }^{48}$

Our findings are summarized in Table 3, which covers nearly the whole of Europe with the exceptions of Iceland, Ireland, Portugal, a few Italian and some smaller German states, and the European territories of the Ottoman Empire. ${ }^{49}$ The data in the first five columns refer to grain prices. Column 1 reports average wheat or rye prices for 1838-1845, and column 2 the

\footnotetext{
${ }^{46}$ A possibly critical case could be the Netherlands, which Stearns (Revolutions, p. 1) would not include in the second group.

${ }^{47}$ See Ó Gráda, Ireland, and for data sources Solar, “Great Famine,” pp. 114f., 120. Note, however, that the absence of data seems equally spread across the different categories. For instance, we also lack grain-price data for Romania and Sicily, which experienced severe political turmoil. For the different states see Stearns, Revolutions; Price, Revolutions; Kaelble, “1848," p. 262f.; and Goldstone, Revolution, p. 285. The two Italian countries in our sample, Lombardy and the Papal States, both experienced strong revolutionary turmoil (see Sperber, European Revolutions, pp. 109f., 222).

${ }^{48}$ See Valentin, Geschichte, vol. 1, for the 1848 revolutions in the German states.

${ }^{49}$ For these countries we were unable to find compatible grain price data extending back to the 1820 s.
} 
TABLE 3

AGRICULTURAL, INDUSTRIAL, AND POLITICAL SHOCKS, 1845-1848

\begin{tabular}{|c|c|c|c|c|c|c|c|c|c|c|}
\hline & \multicolumn{5}{|c|}{ Agriculture } & \multicolumn{3}{|c|}{ Industry } & \multicolumn{2}{|c|}{ Politics } \\
\hline & $\begin{array}{l}\text { Average } \\
\text { Wheat } \\
\text { Price } \\
1838-45^{\mathrm{a}} \\
\quad(1)\end{array}$ & $\begin{array}{l}\text { Maximum } \\
\text { Wheat Price } \\
1845-48^{\mathrm{a}} \\
\text { (Year) } \\
\text { (2) }\end{array}$ & $\begin{array}{c}\text { Years of } \\
\text { High Grain } \\
\text { Prices } \\
1845-47^{\mathrm{b}} \\
(3)\end{array}$ & $\begin{array}{c}\text { Maximum } \\
\text { Price-Forecast } \\
\text { Error } 1845-48 \\
\div \text { SE (Year) } \\
\text { (4) }\end{array}$ & $\begin{array}{c}\text { Grain- } \\
\text { Price } \\
\text { Shock } \\
1845-48 ? \\
(5)\end{array}$ & $\begin{array}{c}1848 \\
\text { Industrial } \\
\text { Growth } \\
(\%) \\
(6)\end{array}$ & $\begin{array}{c}1848 \\
\text { Production- } \\
\text { Forecast } \\
\text { Error } \div \text { SE } \\
\text { (7) }\end{array}$ & $\begin{array}{c}\text { Industrial } \\
\text { Shock in } \\
1848 ? \\
(8)\end{array}$ & $\begin{array}{c}\text { Repression } \\
\text { Before } \\
1848 ? \\
(9)\end{array}$ & $\begin{array}{c}\text { Revolution } \\
\text { in } 1848 ? \\
\quad(10)\end{array}$ \\
\hline Austria & 52.89 & $103.96(47)$ & 3 & $2.72(47)$ & yes & -8.04 & -2.49 & yes & yes & yes \\
\hline Baden & 76.96 & $136.57(47)$ & 3 & $2.31(46)$ & yes & & & & no & yes \\
\hline Bavaria & 70.02 & $127.28(47)$ & 3 & $2.74(47)$ & yes & & & & yes & yes \\
\hline Bohemia & 61.48 & $101.23(47)$ & 2 & $2.41(46)$ & yes & & & & yes & yes \\
\hline France & 93.82 & $149.18(47)$ & 2 & $2.71(47)$ & yes & -10.64 & -2.63 & yes & no & yes \\
\hline Hamburg & 67.11 & $108.72(47)$ & 2 & $2.45(46)$ & yes & & & & no & yes \\
\hline Hesse-Darmstadt & 76.68 & $119.69(47)$ & 3 & $2.24(45)$ & yes & & & & no & yes \\
\hline Hungary & 39.01 & $92.34(47)$ & 3 & $2.38(47)$ & yes & -4.93 & -2.02 & yes & yes & yes \\
\hline Lombardy & 88.32 & $119.13(47)$ & 2 & $2.19(47)$ & yes & & & & yes & yes \\
\hline Mecklenburg-Schw. & 72.91 & $110.89(47)$ & 2 & $2.27(46)$ & yes & & & & yes & yes \\
\hline Papal States & 73.99 & $105.12(47)$ & 2 & $2.56(47)$ & yes & & & & no & yes \\
\hline Switzerland & 87.88 & $146.72(47)$ & 2 & $2.76(47)$ & yes & & & & no & yes \\
\hline Württemberg & 75.90 & $128.70(47)$ & 3 & $2.57(46)$ & yes & & & & no & yes \\
\hline Belgium & 93.80 & $140.13(47)$ & 2 & $2.54(47)$ & yes & & & & no & (yes) \\
\hline Bremen & 76.12 & $109.51(47)$ & 2 & $2.59(47)$ & yes & & & & no & (yes) \\
\hline Brunswick & 62.33 & $100.29(47)$ & 2 & $2.23(47)$ & yes & & & & no & (yes) \\
\hline Denmark & 66.32 & $81.51(47)$ & 2 & $1.16(46)$ & no & & & & no & (yes) \\
\hline Netherlands & 82.58 & $135.99(47)$ & 2 & $2.33(47)$ & yes & -4.06 & 0.57 & no & no & (yes) \\
\hline Oldenburg $^{c}$ & 52.13 & $79.34(47)$ & 3 & $2.51(45)$ & yes & & & & no & (yes) \\
\hline
\end{tabular}


TABLE 3 - continued

\begin{tabular}{|c|c|c|c|c|c|c|c|c|c|c|}
\hline & \multicolumn{5}{|c|}{ Agriculture } & \multicolumn{3}{|c|}{ Industry } & \multicolumn{2}{|c|}{ Politics } \\
\hline & $\begin{array}{l}\text { Average } \\
\text { Wheat } \\
\text { Price } \\
1838-45^{\mathrm{a}} \\
(1)\end{array}$ & $\begin{array}{l}\text { Maximum } \\
\text { Wheat Price } \\
1845-48^{\mathrm{a}} \\
\text { (Year) } \\
\text { (2) }\end{array}$ & $\begin{array}{l}\text { Years of } \\
\text { High Grain } \\
\text { Prices } \\
1845-47^{\mathrm{b}} \\
\text { (3) }\end{array}$ & $\begin{array}{c}\text { Maximum } \\
\text { Price-Forecast } \\
\text { Error } 1845-48 \\
\div \text { SE (Year) } \\
\text { (4) }\end{array}$ & $\begin{array}{c}\text { Grain- } \\
\text { Price } \\
\text { Shock } \\
1845-48 ? \\
\quad(5)\end{array}$ & $\begin{array}{c}1848 \\
\text { Industrial } \\
\text { Growth } \\
(\%) \\
(6)\end{array}$ & $\begin{array}{l}1848 \\
\text { Production- } \\
\text { Forecast } \\
\text { Error } \div \mathrm{SE} \\
\quad(7)\end{array}$ & $\begin{array}{c}\text { Industrial } \\
\text { Shock in } \\
1848 ? \\
(8)\end{array}$ & $\begin{array}{c}\text { Repression } \\
\text { Before } \\
1848 ? \\
(9)\end{array}$ & $\begin{array}{c}\text { Revolution } \\
\text { in } 1848 ? \\
\quad(10)\end{array}$ \\
\hline England & 115.31 & $134.68(47)$ & 1 & $1.81(47)$ & no & 3.94 & 1.09 & no & no & no \\
\hline Norway & 89.28 & $119.74(47)$ & 2 & $2.13(47)$ & yes & & & & no & no \\
\hline Russia $^{\mathrm{c}}$ & 50.72 & $44.12(48)$ & 0 & $-0.10(46)$ & no & & & & yes & no \\
\hline Spain & 105.34 & $141.27(47)$ & 2 & $1.75(47)$ & no & & & & yes & no \\
\hline Sweden & 75.76 & $81.44(45)$ & 1 & $1.25(45)$ & no & 1.69 & 1.08 & no & no & no \\
\hline
\end{tabular}

${ }^{a}$ Grams of fine silver per hectoliter.

${ }^{\mathrm{b}}$ Number of years in which grain prices exceeded the average for 1838-45 (Column 1).

${ }^{\mathrm{c}}$ Rye prices.

Sources: See the Appendix. 
maximum price between 1845 and 1848. Column 3 reports the number of years between 1845 and 1847 in which prices reached heights exceeding the average of 1838-1845. In column 4 the maximum price-forecast error of the years 1845 to 1848 is divided by the corresponding standard error. Whether the deviation of the actual from the forecasted price between 1845 and 1848 was a "shock" in the sense defined above (deviation greater than two standard errors), is indicated in column 5. Columns 6-8 repeat the shock analysis for those countries for which we have industrial production data. If the deviation between actual and forecasted industrial growth is greater than two standard errors, we note a production shock in column 8.

The next step is to confront these results with the political data in the last two columns. Column 9 indicates whether or not the political atmosphere on the eve of 1848 was repressive, and column 10 indicates whether or not a country experienced a revolution in that year. For countries with immediate and substantial constitutional changes but no widespread violence, the "yes" is in parentheses.

Now we are able to give an answer to the question of whether the European revolutions of 1848 were caused, or at least strongly influenced, by short-term economic factors. Comparing columns 8 and 10 we find that, with the exception of the Netherlands, those countries known to have experienced an industrial shock underwent a revolution as well. By contrast, in England and Sweden there was neither an industrial production shock nor a revolution. It is also reassuring that, very much in line with the analysis in the preceding section, the shocks in food prices and manufacturing are highly correlated. Evidence for just seven countries may not be totally persuasive, however. Therefore let us compare columns 5 and 8 , which register the occurrence of shocks in grain prices and manufacturing. Again with the exception of the Netherlands, we find that only countries showing a price shock in 1845-1848 experienced a manufacturing shock in 1848, and viceversa. This finding adds further weight to our hypothesis that a propagation mechanism extended the shock waves of the agrarian crisis into 1848. On the basis of this hypothesis we can compare the earlier price shocks in column 5 directly with the political data for 1848 in column 10 even for those countries for which we do not have production data. The result is surprisingly clear-cut. There is a near-perfect regional match between grain-price shocks and revolutions: among the 21 states experiencing revolutionary turmoil, 20 had been hit by a grain-price shock between 1845 and 1847 . Only Denmark is an outlier. Conversely, of the six countries without a revolution only one, Norway, showed signs of a price shock in the grain market. ${ }^{50}$

\footnotetext{
${ }^{50}$ These results are in line with those of Goldstone (Revolution, pp. 343-48), who finds a high geographical correlation between population pressure and state crises in Europe between 1750 and
} 
The outcome is also remarkably robust with regard to the underlying definition of economic "shocks." As pointed out earlier, the two-standarderror threshold is merely a statistical rule of thumb. However, a comparison of columns 4 and 10 reveals that indeed any threshold value between 1.82 and 2.18 would have yielded the same results, namely that 25 of the 27 cases support our economic view of the 1848 revolutions. ${ }^{51}$ The robustness of the result strongly suggests a positive correlation between the size of the price shock and the likelihood of a revolution. Indeed, a simple logit model exercise reveals that an increase in the pre-1848 grain-price forecast error significantly increases the probability of revolutionary activity. ${ }^{52}$

Note also that less sophisticated measures of the depth of the agrarian crisis lead to comparable findings. For instance, a comparison of columns 3 and 10 shows that the number of years in the period 1845-1847 in which a country suffered from relatively high grain prices is also a remarkably good predictor of revolutionary activity in 1848 . Of the politically stable countries, only Norway and Spain had experienced more than a single year of high grain prices in the previous three. By contrast, all countries undergoing revolution endured a minimum of two years of above-average prices before 1848 .

Is there anything we can say about the outliers? First, regional factors may have played a role. It is interesting to note that the countries for which our hypothesis fails (Denmark, Norway, and the Netherlands) all abut the North Sea, as do all those countries (excepting tiny Brunswick) that experienced some sort of economic trauma in the mid-1840s, and yet avoided violent revolution in 1848 (see Figure 7). Second, institutional and political factors may have been important. An obvious candidate is poor relief, which may have bolstered the dispensing regime's legitimacy. We have, however, found it very difficult to gather comparable information for our sample countries. The most comprehensive comparative study is that of Peter Lindert, who compares ten European countries and finds, significantly

1850. Note, however, that our results are immune to the criticism that the explanatory variable (in our case the price shocks) is endogenous.

${ }^{51}$ Similarly, column 7 shows that any threshold between zero and -2.01 will separate countries with or without shocks in industrial production in a way that is compatible with the economic view (except for the Netherlands).

${ }^{52}$ We have estimated a ML-binary logit model for the occurrence of a revolution, with a constant and the grain-price forecast error in 1847, for the 27 countries or regions in our sample. The LHS variable is constructed as a dummy that takes the value 1 when column 10 in Table 3 shows either a "yes" or a "(yes)," and 0 otherwise. The estimated coefficient for the grain-price forecast error is 1.83 with a SE of 0.57 (significant at the 4 percent level). This translates into an increase in the probability of a revolution for a one-unit increase in the 1847 forecast error from zero of about 21 percentage points. A oneunit increase from a forecast-error level of 1 (2) increases the probability of a revolution by about 46 (23) percentage points. The McFadden- $R^{2}$ is 0.18 . The standard deviation of the 1847 forecast errors is 0.88 . Using the grain-price forecast errors listed in Table 3 , which for some countries deviates from the 1847 figure, does not change the qualitative results. Details are available on request. 


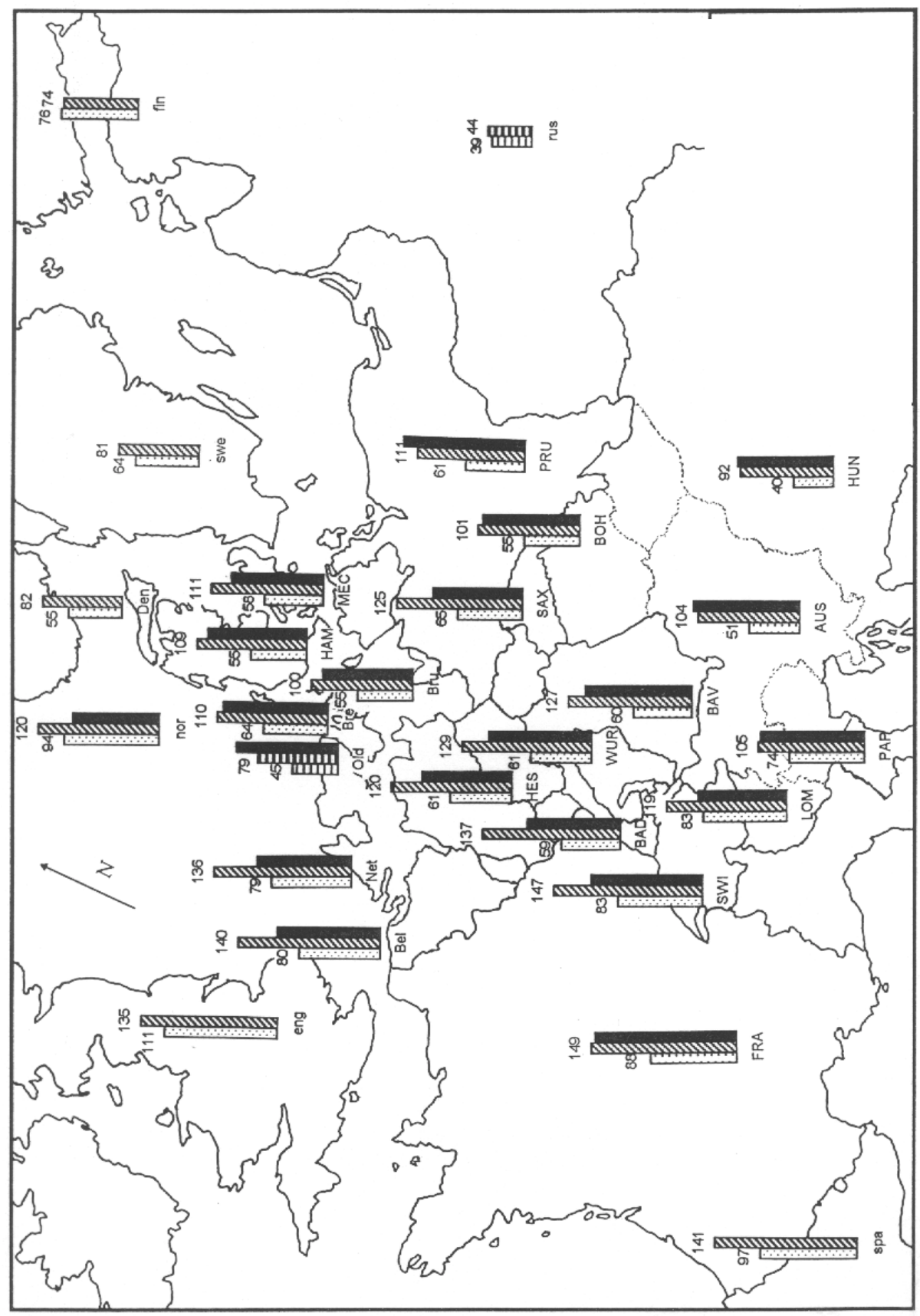

FIGURE 7

WHEAT PRICES IN EUROPE

Notes: Left: average wheat price, 1820-1845. Middle: maximum wheat price, 1845-1848. Right: intensity of price shock (if any). All prices are in grams of fine silver per hectolitre. ABC, Abc, abc: Country with violent revolution, immediate constitutional change, or neither. Source: Table 3, cols. 2 and 4. 
for our purposes, that poor relief per capita in England and the Netherlands were far higher than in the other countries. ${ }^{53}$

One institutional factor that can be assessed, though, is whether a regime was repressive or not. It is interesting that, as column 9 of Table 3 indicates, the North Sea countries were all governed by nonrepressive, liberal regimes. To pursue this idea, we employed the logit model for explaining the likelihood of political revolution in general (discussed above), along with a model explaining violent revolution in particular. We find that whereas an increase in the grain price forecast error significantly increased the likelihood of both violent and preemptive revolution, the presence of a repressive political regime affected only the probability of violence. Violent revolution was significantly likelier to occur under repressive political regimes. ${ }^{54}$ Our findings thus support the idea that the character of the regime largely determined the form of political upheaval in 1848 , but that it was the economic crisis that set the wheels of revolution in motion.

\section{CONCLUSIONS}

Many historians investigating the 1848 revolutions in Europe emphasize the force of ideas as their leading cause. The economic crisis starting with the bad harvest of 1845 is regarded, at most, as one of numerous enabling factors. In view of the analysis put forward in the present study, this view severely underestimates the political dynamics resulting from the extreme economic fluctuations of 1845-1848. A more pointed statement of this view would be that it was economic misery, rather than "ideas," that caused the outbreak of revolutions in early 1848 .

As an initial step, we have here established a propagation mechanism linking the agricultural crisis of 1845-1847 with the subsequent industrial crisis of 1846-1848. Using a number of standard time-series tools, it has been shown that over the period 1820-1850 there was a systematic and significant relationship between agriculture and industry in France, Prussia, Austria, Hungary, and Sweden — but not in England, the world's leading and most highly industrialized economy, nor in the Netherlands. In particular, there is evidence that an increase in grain prices-a good proxy for the cost

\footnotetext{
${ }^{53}$ See Lindert, "Poor Relief," pp. 113-18.

${ }^{54}$ Including a dummy variable that takes the value one when column 9 of Table 3 indicates the presence of a repressive regime in the above-mentioned model explaining the occurrence of revolution (violent or preemptive) produces no significant effects. The ML-binary logit model for the occurrence of violent revolution includes a constant, the grain-price forecast error in 1847, and the dummy variable indicating repression. The LHS variable is constructed as a dummy that takes the value one when column 10 of Table 3 shows a "yes." The estimated coefficients for both the grain-price forecast error (1.43) and the repressive-regime dummy (2.52) are significant at least at the 4 percent level. The McFadden- $R^{2}$ is 0.26 . Again, we arrive at qualitatively similar results when we use the forecast errors as presented in Table 3 instead. Details are available on request.
} 
of living at the time-led after a certain lag to a decline in manufacturing activity. As such, the dramatic increase in food prices in 1845-1847 must have had a strong negative effect on production and employment in the industrial sectors by 1848, the year of political unrest. This result is potentially important. It allows us to draw direct inferences about the occurrence of revolutionary activity from the rich data on European grain prices.

In a second step, we have demonstrated the regional pattern of the economic shocks that hit various European countries prior to 1848 . It turns out that "shocks," defined as significant forecast errors based on an adaptive expectations model, help to predict revolutionary activity: if - and only if - a country was subject to a shock in 1845-1848, it experienced revolution. Using the much sparser available data on manufacturing we find that France, Prussia, Austria, and Hungary suffered a shock-like decline in industrial production in 1848 , paralleled by significant revolutionary activity. While this result is very much in line with the economic view of the 1848 events, it is based on a rather small number of observations. However, making use of the link established above between agriculture and manufacturing, we again turn to grain prices for help. In fact, the regional pattern of grain-price shocks is very similar to that of industrial crises: if a country was subjected to a grain-price shock between 1845 and 1847 , then it went on to undergo revolution in 1848. Of 21 countries subject to a grain price shock, 20 followed this crude but obviously powerful rule, Norway being the peaceful exception. Among the six countries that escaped grain-price shocks, only Denmark experienced far-reaching, and in our sense revolutionary, constitutional reform. These results are very robust with regard to the underlying definition of an economic shock. We conclude that the occurrence of an economic shock in the later 1840s was an important factor in triggering the 1848 revolutions across Europe.

While institutions - namely, the presence or absence of a repressive political regime-add little to the explanation of revolutionary activity as such, we find that they did exert a significant influence on the form that this activity took. The revolutions of 1848 tended to be violent if the regime was repressive. We conclude that the presence of repressive regimes did not trigger revolutionary events, but did help to shape them.

Ideology also played a role, but probably only in combination with economic crisis. The peasants and artisans of the 1840s, suffering a severe deterioration in their socioeconomic status, needed some kind of alternative vision-realistic or otherwise-before they would become revolutionaries. At the time, these alternatives were offered by peasant leaders who appealed to traditional conceptions of fairness (E. P. Thompson's "moral economy" and by politically discontented townsmen who called for liberalism and

55 Thompson, "Moral Economy." 
democracy. In contrast to the crises of $1816 / 17$, when there was still hope that the forces of restoration could be defeated, the crisis of 1845-1848 took place in the context of a much larger and more popular variety of political alternatives that called for immediate action. ${ }^{56}$ Here, at least, we see historical singularities. The likelihood that revolutionary ideology was a necessary condition for upheaval transcends a narrow economistic approach. But although the economic crises did not provide the brains, they did supply the brawn. Revolutionary agitators, pursuing their goals in an undemocratic and often repressive political environment, needed violence (or the credible threat of it) as a political instrument, and only the "crowd" could provide it. ${ }^{57}$ We conclude that without the economic crisis of $1845-1848$, which so obviously endangered the economic welfare of so many people and discredited the ancien régime so thoroughly, there would not have been the critical mass to support these new ideas. Hence no explanation of the European revolutions of 1848 should neglect short-term economic factors.

\section{Appendix: Data Sources}

Political data (intensity of repression, intensity of revolution) are taken for Germany and the Austrian Empire from Huber, Deutsche Verfassungsgeschichte, chs. 7 and 8, and Valentin, Geschichte, chs. 4, 6, and 7. For the European states, see Stearns, Revolutions, Price, Revolutions, Sperber, European Revolutions, and the articles in Dowe, Haupt, and Langewiesche, Europa, ch. 1. Numerous other historical works were consulted which are not in the list of references. Please contact the authors for a list.

Grain-price data would ideally be an average for the harvest year, weighted by sales and expressed in, well, euros. The currency problem can quite easily be overcome by transforming recorded local prices per local unit into grams of fine silver per hectoliter. For the conversion of currencies, measures of capacity, and measures of weight we used Klimpert, Lexikon, at times checked by and supplemented with data in other literature on the subject. As both the levels and the volatility of the data are strongly influenced by the way the average is calculated, we have ignored the few available series for the harvest year or ones which relied only on one or two dates per year. This, for example, is the case for the Lisbon price series of Magalhães Godinho, Prix, pp. 76-78. Very probably the only series that is partially weighted by sales is the one for France, where the weighting was (or was supposed to be) done at the very first level of recording (see Drame et al., Siècle, ch. 4). Whenever possible, we have tried to find data for the country's capital, because these were the prices actually observed (and responded to) in the political center. If not stated otherwise, the data are available annually from 1815 to 1850. The abbreviations in parentheses are the country codes used in Figure 7. Country codes in capitals stand for violent revolutions; initial capitals mean preemptive revolution; lower case means no revolution.

\footnotetext{
${ }^{56}$ The similar food-price increase of $1854-1855$ created neither famine nor social unrest; see C. Tilly et al., Rebellious Century.

${ }^{57}$ Hobsbawm has termed this "bargaining by riot" ("Machine Breakers," p. 57).
} 
1. Austria (AUS; Lower Austria, contains Vienna): Földes, "Getreidepreise," p. 484; mining and industrial production 1830-50 Komlos, Habsburg Monarchy, pp. $294 \mathrm{f}$.

2. Baden (BAD; Mannheim, Heidelberg): "Getreidepreise in Deutschland," p. I.297.

3. Bavaria (BAV; Munich): Seuffert, Statistik, p. 124.

4. Belgium (Bel): Seuffert, Statistik, p. 401.

5. Bohemia (BOH; Prague): Schebek, Collektiv-Ausstellung, pp. 99-101.

6. Bremen (Bre): Gerhard and Kaufhold, Preise, pp. $204 f$.

7. Brunswick (Bru): Soetbeer, Beiträge, p. 8.

8. Denmark (Den; Copenhagen, 1819-50): Weisz, "Getreidepreise," p. 397, wheat prices 1819-32 extrapolated by using rye prices from Földes, "Getreidepreise," p. 489. The correlation between the wheat and rye series $1833-50$ is 0.72 .

9. England (eng; London): Rostow, British Economy, p. 125, cf. also Weisz, "Getreidepreise," p. 350; British industrial production Crafts and Harley, "Output Growth," p. 727.

10. Finland (fin): Földes, "Getreidepreise," p. 492.

11. France (FRA; département Seine-et-Oise, surrounds Paris): Labrousse, Romano, and Dreyfus, Prix, 196f.; industrial production 1820-50 Lévy-Leboyer and Bouguignon, French economy, table A-IV.

12. Hamburg (HAM): "Getreidepreise in Deutschland," p. I.296.

13. Hesse (HES; 1822-50): Mittheilungen der hessischen Zentralstelle, p. 334.

14. Hungary (HUN; Pest, 1819-50): Földes, “Getreidepreise," p. 485; mining and industrial production 1830-50 Komlos, Habsburg Monarchy, p. $294 \mathrm{f}$.

15. Lombardy (LOM; Milan): Maddalena, Prezzi, p. 379.

16. Mecklenburg (MEC; Rostock): "Getreidepreise im Grossherzogthum Mecklenburg," pp. 26, 28.

17. Netherlands (Net; Utrecht): Posthumus and Ketner, Inquiry, pp. 422f.; industrial production Smits, Horlings, and van Zanden, "Measurement," pp. $62 \mathrm{f}$.

18. Norway (nor; 1820-50): Földes, "Getreidepreise," p. 518.

19. Oldenburg (Old; rye prices 1817-50): "Durchschnittspreise," p. 5.

20. Papal States (PAP; Rome): Földes, "Getreidepreise," p. 482.

21. Prussia (PRU; Berlin): 1815 Seuffert, Statistik, p. 386; 1816-60 Engel, "Getreidepreise," p. 257; woolen weaving production 1828-50 Blumberg, Deutsche Textilindustrie, p. 382.

22. Russia (rus; Moscow, rye prices): Mironov, Chlebnie ceny, pp. 235-37.

23. Saxonia (SAX; Dresden 1820-50): Mittheilungen des statistischen Vereins, pp. 66f. (1820-31, obvious misprint for 1821 corrected), Seuffert, Statistik, p. 375 (1832-50).

24. Spain (spa; Barcelona): price index $(1913=100)$ from Sardà, Política Monetaria, pp. 303-05, rebased in prices by Consejo Superior Bancario, Dictamen, pp. 39, 109. Obvious misprint for 1848 corrected.

25. Sweden (swe; Stockholm): Jörberg, History of Prices, pp. 124-27; industrial production Schön, Historiska nationalräkenskaper, table II.

26. Switzerland (swi): Historische Statistik, p. 480.

27. Württemberg (WUR): Mährlen and Trüdinger, “Durchschnittspreise," II.120f.

\section{REFERENCES}

Abel, Wilhelm. Agrarkrisen und Agrarkonjunktur. 3rd edn. Hamburg: Parey, 1978.

Amtsblatt der Königlichen Regierung zu Potsdam und der Stadt Berlin. Nowawes 1840-1849.

Bass, Hans-Heinrich. Hungerkrisen in Preußen während der ersten Hälfte des 19. Jahr- 
hunderts. St. Katharinen: Scripta Mercaturae, 1991.

Bauernfeind, Walter, and Ulrich Woitek. "Agrarian Cycles in Germany 1339-1670: A Spectral Analysis of Grain Prices and Output in Nuremberg." Explorations in Economic History 33, no. 4 (1996): 459-78.

Bergmann, Jürgen. "Ökonomische Voraussetzungen der Revolution von 1848. Zur Krise von 1845 bis 1848 in Deutschland." In Geschichte als politische Wissenschaft, edited by Jürgen Bergmann, Klaus Megerle, and Peter Steinbach, 24-54. Stuttgart: KlettCotta, 1979.

. Wirtschaftskrise und Revolution. Handwerker und Arbeiter 1848/49. Stuttgart: Klett-Cotta, 1986.

Blumberg, Horst. Die deutsche Textilindustrie in der industriellen Revolution. Berlin: Akademie, 1965.

Boot, H. M. The Commercial Crisis of 1847. Hull: Hull University Press, 1984.

Braudel, Fernand P., and Frank Spooner. "Prices in Europe from 1450 to 1750." In The Cambridge Economic History of Europe, edited by M. M. Postan, vol. 4, 374-486. Cambridge: Cambridge University Press, 1967.

Broers, Michael. Europe after Napoleon: Revolution, Reaction and Romanticism, 1814-1848. Manchester: Manchester University Press, 1996.

Bruckmüller, Ernst, and Wolfgang Häusler, eds. 1848. Revolution in Österreich. Vienna: öbv \& hpt, 1999.

Consejo Superior Bancario. Dictamen de la Comisión nombrada por Real orden de 9 de enero de 1929, para el estudio de la implantación del patrón de oro. Madrid: Samarán, 1929.

Crafts, N. F. R., and C. Knick Harley. "Output Growth and the British Industrial Revolution.” Economic History Review 45, no. 4 (1992): 703-30.

Dipper, Christof, and Ulrich Speck, eds. 1848. Revolution in Deutschland. Frankfurt/Main: Insel, 1998.

Dowe, Dieter, Heinz-Gerhard Haupt, and Dieter Langewiesche, eds. Europa 1848. Bonn: Dietz, 1998.

Drame, Sylvie, et al. Un siècle de commerce du blé en France 1825-1913. Paris: Economica, 1991.

"Durchschnittspreise des Getreides und einiger anderen Nahrungsmittel im Grossherzogthum Oldenburg aus den Jahren 1817 bis 1858." Statistische Nachrichten über das Grossherzogthum Oldenburg 4 (1860): 1-43.

Ebeling, Dietrich, and Franz Irsigler. "Zur Entwicklung von Agrar- und Lebensmittelpreisen in der vorindustriellen und industriellen Zeit." Archiv für Sozialgeschichte 19, no. 1 (1979): 299-329.

Engel, Ernst. "Die Getreidepreise, die Ernteerträge und der Getreidehandel im preussischen Staate.” Zeitschrift des Königl. Preussischen Statistischen Bureaus 1 (1861): 249-89.

Ernst, Andreas, Albert Tanner, and Matthias Weishaupt, eds. Revolution und Innovation. Die konfliktreiche Entstehung des schweizerischen Bundesstaates von 1848. Zurich: Chronos, 1998.

Fischer, Holger, ed. Die ungarische Revolution von 1848/49. Vergleichende Aspekte der Revolutionen in Ungarn und Deutschland. Hamburg: Krämer, 1998.

Földes, Béla. “Die Getreidepreise im 19. Jahrhundert." Jahrbücher für Nationalökonomie und Statistik, 3rd series 29 (1905): 467-518.

Fremdling, Rainer, and Gerd Hohorst. "Marktintegration der preußischen Wirtschaft im 19. Jahrhundert." In Industrialisierung und Raum, edited by Rainer Fremdling and Richard Tilly, 57-104. Stuttgart: Klett-Cotta, 1979.

Gailus, Manfred. Straße und Brot. Sozialer Protest in den deutschen Staaten unter 
besonderer Berücksichtigung Preußens, 1847-1849. Göttingen: Vandenhoeck \& Ruprecht, 1990.

Gall, Lothar, ed. 1848: Aufbruch zur Freiheit. Berlin: Nicolai, 1998.

Gerhard, Hans-Jürgen, ed. Löhne im vor- und frühindustriellen Deutschland. Göttingen: Schwartz, 1984.

Gerhard, Hans-Jürgen, and Karl Heinrich Kaufhold. Preise im vor- und frühindustriellen Deutschland. Grundnahrungsmittel. Göttingen: Schwartz, 1990.

"Die Getreidepreise im Grossherzogthum Mecklenburg-Schwerin während des Zeitraums von 1771 bis 1870." Beiträge zur Statistik Mecklenburgs 7, no. 3/4 (1873).

"Die Getreidepreise in Deutschland seit dem Ausgang des 18. Jahrhunderts." Vierteljahrshefte zur Statistik des Deutschen Reichs 44 (1935): I.273-321.

Goldstone, Jack A. Revolution and Rebellion in the Early Modern World. Berkeley: University of California Press, 1991.

Gömmel, Rainer. Realeinkommen in Deutschland. Ein internationaler Vergleich (1810-1914). Nuremberg: University of Nuremberg, 1978.

Greene, William H. Econometric Analysis. 2nd edn. New York: Macmillan, 1993.

Hahn, Hans-Werner. "Die sozioökonomische Ordnung der Nation." In Revolution in Deutschland 1848, edited by Christof Dipper and Ulrich Speck, 366-80. Frankfurt/ Main: Insel, 1998.

Hardtwig, Wolfgang, ed. Revolution in Deutschland und Europa 1848/49. Göttingen: Vandenhoeck \& Ruprecht, 1989.

Hein, Dieter. Die Revolution von 1848/49. Munich: Beck, 1998.

Hildbrand, Thomas, and Albert Tanner, ed. Im Zeichen der Revolution: der Weg zum schweizerischen Bundesstaat 1798-1848. Zurich: Chronos, 1997.

Historische Statistik der Schweiz. Zurich: Chronos, 1996.

Höbelt, Lothar. 1848-Österreich und die deutsche Revolution. Wien: Amalthea, 1998.

Hobsbawm, Eric. "Economic Fluctuations and Some Social Movements since 1800." Economic History Review 5, no. 1 (1952): 1-25.

. "The Machine Breakers.” Past and Present 1, no. 1 (1952): 57-70.

Homer, Sidney. A History of Interest Rates. 2nd edn. New Brunswick: Rutgers, 1977.

Huber, Ernst. Deutsche Verfassungsgeschichte. Vol. 2. Der Kampf um Einheit und Freiheit 1830 bis 1850. 2nd edn. Stuttgart: Kohlhammer, 1968.

Jacobs, Alfred, and Hans Richter. Die Großhandelspreise in Deutschland von 1792 bis 1934. Berlin: Hanseatische Verlagsanstalt, 1935.

Jansen, Christian, and Thomas Mergel, eds. Die Revolution von 1848/49. Göttingen: Vandenhoeck \& Ruprecht, 1998.

Jörberg, Lennart. A History of Prices in Sweden 1732-1914. Vol. 1. Lund: CWK Gleerup, 1972.

Judson, Pieter M. Wien brennt. Die Revolution von 1848 und ihr liberales Erbe. Vienna: Böhlau, 1998.

Kaelble, Hartmut. "1848: Viele nationale Revolutionen oder eine europäische Revolution?" In Revolution in Deutschland und Europa 1848/49, edited by Wolfgang Hardtwig, 260-78. Göttingen: Vandenhoeck \& Ruprecht, 1998.

Kimmel, Michael S. Revolution. A Sociological Interpretation. Cambridge: Polity Press, 1990.

Klimpert, Richard. Lexikon der Münzen, Maße, Gewichte, Zählarten und Zeitgrößen aller Länder dieser Erde. 2nd edn. Berlin: Regenhardt, 1896.

Komlos, John. The Habsburg Monarchy as a Customs Union. Economic Development in Austria-Hungary in the Nineteenth Century. Princeton: Princeton University Press, 1983. 
Kopsidis, Michael. "Marktintegration und Entwicklung der westfälischen Landwirtschaft 1780-1880.” Ph.D. diss, University of Munster, 1995.

Kuczynski, Jürgen. "Die wirtschaftlichen und sozialen Voraussetzungen der Revolution von 1848/1849." In Zur Frühgeschichte der deutschen Gewerkschaftsbewegung 1800-1849, edited by Elisabeth Todt and Hans Radandt, 7-32. Berlin: Freie Gewerkschaft, 1950.

. Die Lage der Arbeiter unter dem Kapitalismus. Vol. 1. Darstellung der Lage der Arbeiter in Deutschland von 1789 bis 1849. Vol. 2. Studien zur Geschichte der zyklischen Überproduktion in Deutschland 1825 bis 1866. Berlin: Akademie 1961.

Labrousse, Ernest. “1848, 1830, 1789. Comment naissent révolutions.” In Actes du congrès historique du centenaire de la révolution de 1848, 1-29. Paris: Presses Universitaires de France, 1948.

. "Panoramas de la crise." In Aspects de la crise et de la dépression de l'économie française au milieu du XIX ${ }^{e}$ siècle 1846-1851, edited by Ernest Labrousse, iii-xxiv. Paris: Presses Universitaires de France, 1956.

Labrousse, Ernest, Ruggiero Romano, and F.-G. Dreyfus. Le prix du froment en France au temps de la monnaie stable (1726-1913). Paris: SEVPEN, 1970.

Langewiesche, Dieter, ed. Die Revolutionen von 1848 in der europäischen Geschichte: Ergebnisse und Nachwirkungen. Munich: Oldenbourg, 2000.

Lévêque, Pierre. "Ébranlement et restauration de l'ordre social." In La révolution de 1848 en France et en Europe, edited by Sylvie Aprile et al., 69-126. Paris: Édition sociales, 1998.

Lévy-Leboyer, Maurice, and François Bourguignon. The French Economy in the Nineteenth Century. Cambridge: Cambridge University Press, 1990.

Lichter, Jörg. Preußische Notenbankpolitik in der Formationsphase des Zentralbanksystems. Berlin: Duncker \& Humblot, 1999.

Lill, Rudolf, ed. Die Revolution von 1848/49 in Deutschland und Europa. Karlsruhe: Kulturreferat der Stadt, 1998.

Lindert, Peter. "Poor Relief Before the Welfare State: Britain Versus the Continent." European Review of Economic History 2, no. 2 (1998): 101-40.

Maddalena, Aldo de. Prezzi e Mercedi a Milano dal 1701 al 1860. Milan: Banca Commerciale, 1974.

Magalhães Godinho, Vitorino. Prix et Monnaies au Portugal 1750-1850. Paris: Colin, 1955.

Mährlen, Hermann, and O. Trüdinger. "Die Durchschnittspreise von Getreide in Württemberg 1766-1895." Württembergische Jahrbücher für Statistik und Landeskunde (1896): II.117-22.

Mironov, Boris N. Chlebnye ceny v Rossii za dva stoletija (XVIII-XIX vv.). Leningrad: Nauka, 1985.

Mitchell, B. R. International Historical Statistics. Europe 1750-1988. 3rd edn. New York: Stockton, 1992.

Mittheilungen der hessischen Zentralstelle für die Landesstatistik 5 (1871).

Mittheilungen des statistischen Vereins für das Königreich Sachsen 2 (1832).

Mommsen, Wolfgang J. 1848: Die ungewollte Revolution. Die revolutionären Bewegungen in Europa 1830-1849. Frankfurt/Main: Fischer, 1998.

Obermann, Karl. "Wirtschafts- und sozialpolitische Aspekte der Krise von 1845-1847 in Deutschland, insbesondere in Preußen." Jahrbuch für Geschichte 7 (1972): 141-74.

Ó Gráda, Cormac. Ireland Before and After the Famine. Explorations in Economic History, 1800-1925. 2nd edn. Manchester: Manchester University Press, 1993.

Phelps Brown, Ernest H., and Sheila V. Hopkins. "Seven Centuries of the Prices of 
Consumables, Compared with Builders' Wage-Rates." Economica 23 (1956): 296-314.

Pinkney, David H. Decisive Years in France, 1840-1847. Princeton: Princeton University Press, 1986.

Posthumus, Nicolaas W., and F. Ketner. Inquiry into the History of Prices in Holland. Vol. 2. Leiden: Brill, 1964.

Price, Roger. The Revolutions of 1848. Atlantic Highlands, NJ: Humanities Press, 1989.

Rill, Bernd, ed. 1848. Epochenjahr für Demokratie und Rechtsstaat in Deutschland. Munich: Hanns-Seidel-Stiftung, 1998.

Roscher, Wilhelm. Über Kornhandel und Theuerungspolitik. 3rd edn. Stuttgart: Cotta, 1852.

Rostow, Walt W. British Economy of the Nineteenth Century. Oxford: Oxford University Press, 1948.

Rudé, George. "Why Was There No Revolution in England in 1830 or 1848?" In Studien über die Revolution, edited by Manfred Kossok, 231-44. Berlin: Akademie, 1969.

Saalfeld, Diedrich. "Lebensverhältnisse der Unterschichten Deutschlands im neunzehnten Jahrhundert.” International Review of Social History 28, no. 3 (1983): 215-53.

Sardà, Juan. La Política Monetaria y las fluctaciones de la Economía española en el siglo XIX. Madrid: Diana, 1948.

Schebek, Edmund. Collektiv-Ausstellung von Beiträgen zur Geschichte der Preise veranstaltet zur Welt-Ausstellung 1873 Wien von der Handels- und Gewerbekammer in Prag. Prague: Mercy, 1873.

Schön, Lennart. Historiska nationalräkenskaper för Sverige: Industri och hantverk 1800-1980. Lund: Ekonomisk-historika föreningen, 1988.

Schroeder, Paul W. The Transformation of European Politics 1763-1848. Oxford: Clarendon, 1994.

Seuffert, Georg K. Statistik des Getreide- und Viktualien-Handels im Königreich Bayern mit Berücksichtigung des Auslandes. Munich: Weiß, 1857.

Siegenthaler, Hansjörg. Regelvertrauen, Prosperität und Krisen. Die Ungleichmäßigkeit wirtschaftlicher und sozialer Entwicklung als Ergebnis individuellen Handelns und sozialen Lernens. Tübingen: Mohr Siebeck, 1993.

Siemann, Wolfram. Die deutsche Revolution von 1848/49. Frankfurt/Main: Suhrkamp, 1985.

Sigmann, Jean. 1848. Les révolutions romantiques et democratiques de l'Europe. Paris: Calmann-Lévy, 1970.

Smits, J. P., E. Horlings, and J. L. van Zanden. "The Measurement of Gross National Product and its Components. The Netherlands, 1800-1913." Research Memorandum No. 1, N. W. Posthumus Institute, Utrecht University, 1997.

Soetbeer, Adolph. Beiträge zur Statistik der Preise, Hamburg: Kümpel, 1858.

Solar, Peter. "The Great Famine Was No Ordinary Subsistence Crisis." In Famine: the Irish Experience, 900-1900, edited by E. Margaret Crawford, 112-33. Edinburgh: Donald, 1989.

Sperber, Jonathan. The European Revolutions, 1848-1851. Cambridge: Cambridge University Press, 1994.

Spree, Reinhard, and Jürgen Bergmann. "Die konjunkturelle Entwicklung der deutschen Wirtschaft 1840 bis 1864.” In Sozialgeschichte heute, edited by Hans-Ulrich Wehler, 289-325. Göttingen: Vandenhoeck \& Ruprecht, 1974.

Stearns, Peter N. The Revolutions of 1848. London: Weidenfeld \& Nicolson, 1974. Stürmer, Michael. Crise, révolution et conjoncture 1848-1849. Bonn: Bouvier, 1999.

Thompson, E. P. "The Moral Economy of the English Crowd in the Eighteenth Century." 
Past and Present 50, no. 1 (1971): 76-136.

Tilly, Charles. "Revolutions and Collective Violence." In Handbook of Political Science, edited by Fred I. Greenstein and Nelson W. Polsby, vol. 3, 483-555. Reading: Addison-Wesley, 1975.

. European Revolutions, 1492-1992. Oxford: Blackwell, 1993.

Tilly, Charles, Louise Tilly, and Richard H. Tilly. The Rebellious Century, 1830-1930. Harvard: Harvard University Press, 1975.

Tilly, Richard H. "Popular Disorders in 19th Century Germany. A Preliminary Survey." Journal of Social History 4, no. 1 (1970): 1-40.

Vom Zollverein zum Industriestaat. Die wirtschaftlich-soziale Entwicklung Deutschlands 1834 bis 1914. Munich: dtv, 1990.

Timmermann, Heiner, ed. 1848. Revolution in Europa. Verlauf, politische Programme, Folgen und Wirkungen. Berlin: Duncker \& Humblot, 1999.

Tocqueville, Alexis de. L'ancien régime et la revolution. 2nd edn. Paris: Lévy, 1856.

Valentin, Veit. Geschichte der deutschen Revolution von 1848-49. Vol. 1. Weinheim: Beltz Quadriga, 1998. [Originally published 1930]

Ward-Perkins, C. N. "The Commercial Crisis of 1847." Oxford Economic Papers 2, no. 2 (1950): 75-94.

Wehler, Hans-Ulrich. Deutsche Gesellschaftsgeschichte. Vol. 2. Von der Reformära bis zur industriellen und politischen "Deutschen Doppelrevolution.” Munich: Beck, 1989.

Weir, David R. "Les crises économiques et les origines de la Révolution française." Annales E.S.C. 46, no. 5 (1991): 917-51.

Weisz, B. "Die Getreidepreise im XIX. Jahrhundert mit besonderer Berücksichtigung der Preis-Schwankungen.” Statistische Monatsschrift 3 (1877): 345-70, 393-401.

Williamson, Jeffrey. “The Impact of the Corn Laws Just Prior to Repeal." Explorations in Economic History 27, no. 2 (1990): 123-56. 